\title{
(Re)embracing social responsibility theory as a basis for media speech: shifting the normative paradigm for a modern media
}

\author{
Peter COE*
}

\author{
Anthony Collins Solicitors LLP; Institute of Advanced Legal Studies' \\ Information Law and Policy Centre, University of London
}

\begin{abstract}
Dave Egger's fictional book. The Circle tells the story of an all-powerful new media company of the same name that seeks to totally monopolise its market and remake the world in its image. To achieve this The Circle advocates the unregulated sharing of all information, at all times, regardless of its source and irrespective of the consequences for individuals, society and the state. Although the dystopian view of reality presented by the book is perhaps slightly extreme, it does not take any great leap of faith to see how we could all end up as 'Circlers', particularly because the underlying normative rationale that drives The Circle is what currently underpins online speech in reality. Libertarianism and the inberently libertarian arguments from truth and the marketplace of ideas have historically underpinned the notion of the Fourth Estate and have a 'bold' on First Amendment jurisprudence. In recent years, libertarianism has emerged as the de facto normative paradigm for internet and social media speech worldwide. Although the theory's dominant position fits with the perceived ethos of social media platforms such as Facebook, its philosophical foundations are based on nineteenth and early twentieth-century means of communication. Consequently, as illustrated by issues such as filter bubbles and Facebook's reaction to fake news (bringing in a third-party fact-checking company) which conflicts with the platform's libertarian ideology, as well as the European Court of Human Rights consistently placing the argument from democracy at the heart of its Article $10 \mathrm{ECHR}$ jurisprudence, rather than the argument from truth and marketplace of ideas, this normative framework is idealistic as opposed to being realistic. Therefore, it is not suitable for twenty-first-century free speech and the modern media, of which social media is no longer an outlier, but a central component. Thus, this paper advances the argument that a normative and philosophical framework for media speech, based on social responsibility theory and the argument from democratic self-governance, is more suitable for the modern media than libertarianism. Further, it justifies a coercive regulatory regime that also preserves media freedom.
\end{abstract}

Keywords: social media; online speech; free speech theory; libertarianism; social responsibility theory; media freedom

* Barrister and Associate, Anthony Collins LLP; Research Associate, Institute of Advanced Legal Studies Information Law and Policy Centre, University of London; Associate Academic Member, Cornwall Street Chambers; Door Tenant, East Anglian Chambers. Formerly, Senior Lecturer in Law, Aston Law School, Aston University (UK). This article was presented as a paper at 'Joining the Circle: Capturing the Zeitgeist of "Big Tech" Companies, Social Media Speech and Privacy' conference, Inner Temple, 23 May 2018. The author would like to thank Dr Paul Wragg (University of Leeds), Dr András Koltay (Pázmány Péter Catholic University) and Professor Tom Gibbons (University of Manchester) for comments on earlier drafts of this article. The usual disclaimer applies. 


\section{Introduction}

$\mathrm{T}$ his paper begins at Section 2 by introducing libertarianism's position as the dominant communication theory for free speech generally and the de facto normative paradigm for online speech. Based on analysis of the argument from truth and the marketplace of ideas, Section 3 advances the argument that libertarianism should be rejected as a normative communication paradigm, particularly in the context of the modern media within which the internet and social media are no longer outliers of free speech, but are central to how we impart and receive information and ideas. This leads on to Section 4 in which it is argued that the social responsibility communication theory should be re-embraced as a normative paradigm. It argues that this theory, combined with the argument from democratic selfgovernance, provides a more suitable normative and philosophical framework for the modern media than libertarianism. This is because the framework not only rights a number of issues created by libertarianism, but also justifies a coercive regulatory regime for the media that also preserves media freedom.

\section{Introducing libertarianism: the de facto normative paradigm for free speech?}

Early libertarians such as John Milton ${ }^{1}$ and John Erskine ${ }^{2}$ argued that if individuals could be freed from restrictions on communication, people would 'naturally' follow the dictates of their conscience, seek truth, engage in public debate and, consequently, create a better life for themselves and others. ${ }^{3}$ In applying the theory to the modern media, from a 'pure' libertarian perspective, according to Merrill, it should be characterised by 'uncontrolled, full, unregulated laissez-faire journalism - with a clear separation of State and [media]'. ${ }^{4}$ In Merrill's view, freedom should be the underlying moral principle of any press theory: ' $\mathrm{t}]$ here is a basic faith, shown by libertarian advocates, that a free press - working in a laissez-faire, unfettered situation - will naturally result in a pluralism of information and viewpoints necessary in a democratic society'. 5

In the context of online and social media speech, this correlates closely with the view of cyber-libertarians who, according to Nemes, 'argue that the harm in regulating online speech is greater than the harm caused by the online speech' 6 and 'favour an archaic, unregulated Internet free from state control, fearing that regulation will stifle Internet development and associated freedoms'. ${ }^{7}$ Echoing these sentiments, in The Circle we are told that 'life will be better, will be perfect, when everyone has unfettered access to everyone and everything they know ... all information, personal or not, should be known

1 Milton's Areopagitica, which was published in 1644, provided strong libertarian arguments against authoritarian controls of free speech and the press and for intellectual freedom. Milton's tract laid down the self-righting process, which underpins libertarianism and is enshrined within the marketplace of ideas theory. J Milton, Areopagitica (Clarendon Press Series, Leopold Classic Library 2016).

2 Some 50 years after Milton published Areopagitica, John Erskine advanced the libertarian principles of freedom of speech and of the press in defence of publishers accused of violating the law. See: T Howell, $A$ Complete Collection of State Trials London: 1704, vol 22 (TC Howard 1817) 414.

3 S Baran and D Davis, Mass Communication Theory: Foundations, Ferment and Future 7th edn (Wadsworth Publishing 2014) 63.

$4 \mathrm{~J}$ Merrill, The Imperative of Freedom: A Philosophy of Journalistic Autonomy (Freedom House 1990) 11.

5 Ibid 35.

6 I Nemes, 'Regulating hate speech in cyberspace: issues of desirability and efficacy' (2002) 11(3) Information and Communication Technology Law 196.

7 Ibid 199. See also B Leiter, 'Clearing cyber-cesspools: Google and free speech' in S Levmore and M Nussbaum (eds), The Offensive Internet (Harvard University Press 2010) 156; J Bartlett, The Dark Net (Random House 2014) 8-9. 
by all'. ${ }^{8}$ Although perhaps not as extreme, in 'real life' in late 2016, Mark Zuckerberg reiterated that Facebook simply distributes content created by its users, using an impersonal and objective algorithm. ${ }^{9}$ In his view, the social network is essentially a platform for others to disseminate speech, and nothing more, and is certainly not a censor or arbiter of truth. ${ }^{10}$

The underlying principles in The Circle's mission and Zuckerberg's statement are aligned to libertarianism, which dictates that free speech is an intrinsic natural right that individuals are born with and, therefore, it is absolute, as it does not propagate duties and responsibilities that attach to the right to free speech and, by extension, in a European context at least, media freedom. ${ }^{11}$ From an Anglo-American perspective, the theory and, as discussed below, the arguments advanced by proponents such as John Milton, John Erskine, John Stuart Mill, Thomas Jefferson ${ }^{12}$ and Justice Holmes have served to support the traditional notion of the Fourth Estate. ${ }^{13}$ In the USA, the theory was made an explicit and foundational tenet of democracy, as it is enshrined within the First Amendment, ${ }^{14}$ pursuant to which 'Congress shall make no law . . . abridging the freedom of speech, or of the press.' ${ }^{15}$ Central to the influence of libertarianism on free speech has been Milton's self-righting process, Mill's argument from truth and, in particular, Justice Holmes' marketplace of ideas theory ${ }^{16}$ that was laid down in Abrams $v$ United States. ${ }^{17}$ This theory encapsulates the self-righting process as it is based on the premise that 'truth', or the 'best'

8 D Eggers, The Circle (Penguin 2013) 483-4.

9 M Ingram, 'Mark Zuckerberg finally admits Facebook is a media company' <www.fortune.com> (23 December 2016), <http://fortune.com/2016/12/23/zuckerberg-media-company>; M Ingram, 'Facebook's claim that it isn't a media company is getting harder to swallow' <www.fortune.com> (15 December 2016) <http:/ fortune.com/2016/12/15/facebook-media-claim>.

10 Ibid.

11 Although Article 10(1) ECHR does not specifically provide for protection of media freedom in distinction to that of private individuals and non-media institutions, in interpreting Article 10, the ECtHR has attached great importance to the role of the media. For example, see Bladet Tromso and Stensaas v Norway (2000) 29 EHRR 125, [59]; Bergens Tidande v Norway (2001) 31 EHRR 16, [48]; Busuioc v Moldova (2006) 42 EHRR 14, [64]-[65]; Jersild v Denmark (1995) 19 EHRR 1; Janowski v Poland (No 1) (2000) 29 EHRR 705, [32]. Compare with the position in the USA where the US Supreme Court has consistently resisted arguments that the free press clause 'or of the press' in the First Amendment to the US Constitution creates a similar distinction to that provided by the jurisprudence of the Strasbourg Court. For example, see: majority decision in Citizens United $v$ FEC 130 S Ct, 905. For detailed analysis see: P Coe, "Redefining “media” using a "media-as-a-constitutionalcomponent" concept: an evaluation of the need for the European Court of Human Rights to alter its understanding of "media" within a new media landscape' (2017) 37(1) Legal Studies 25-53, 49.

12 Jefferson, during his presidency, consistently emphasised the theory in his defence of freedom of the press. For example, see T Jefferson, The Writings of Thomas Jefferson, vol 11, A Lipscomb (ed) (Memorial Edition, Thomas Jefferson Memorial Association 1904) 32-4.

13 D Weiss, 'Journalism and theories of the press' in S Littlejohn and K Foss (eds), Encyclopedia of Communication Theory, vol 2 (Sage 2009) 574-9, 576. See ch 1, section 3.1, for an explanation of the meaning of 'Fourth Estate'

14 Ibid; P Plaisance, 'The mass media as discursive network: building on the implications of libertarian and communitarian claims for new media ethics theory' (2005) 15(3) Communication Theory 292-313, 295.

15 Consequently, US Supreme Court decisions have consistently defended media freedom from government intervention and regulation based on libertarian ideology. For example, see New York Times v Sullivan 376 US 254 (1964); New York Times v United States 403 US 713 (1971). See generally P Stewart J, 'Or of the press' (1975) 26 Hastings Law Journal 631; ch 2, section 2.

16 See Baran and Davis (n 3) 68; Weiss (n 13) 577; F Siebert, T Peterson and W Schramm, Four Theories of the Press (University of Illinois Press 1956) 44-5.

17250 US 616 (1919). 
ideas, will win out, as they will naturally emerge from the competition of ideas in the marketplace. ${ }^{18}$ Thus, as Barendt observes:

It is almost impossible to exaggerate the central hold of the 'market-place of ideas' metaphor on US jurisprudence and general thinking about the First Amendment freedom of speech. From it stems the belief that the best corrective for the expression of pernicious opinion is not regulation, let alone suppression, but more speech. Truth, it is said, will emerge from the competition of ideas in the market-place ... This is the central tradition of US free speech jurisprudence ... it is now taken quite literally as the appropriate framework for First Amendment jurisprudence. ${ }^{19}$

Indeed, it is because of Mill's argument from truth and the introduction by Justice Holmes of the marketplace of ideas that libertarian free speech ideology continued to thrive in the nineteenth century and on into the twentieth. ${ }^{20}$ Although the twentieth century saw the Royal Commission on the Press ${ }^{21}$ in the UK and the Hutchins Commission report ${ }^{22}$ in the US, which were both catalysts for the emergence of the social responsibility theory, ${ }^{23}$ this 'doctrine has always been relegated to the fringes of journalism education and the newsroom'. ${ }^{24}$ This marginalisation of the social responsibility doctrine is certainly the case in respect of the internet and social media speech. For the reasons articulated by cyber-libertarians above, ${ }^{25}$ as Dahlberg states, the internet has provided the perfect environment for libertarianism and, specifically, the marketplace of ideas theory to flourish as it 'provides a space for information exchange and individual decision-making free of bureaucracy, administrative power and other restrictions of "real" space'. 26 Thus, it has been recognised by a number of scholars that libertarianism has become the de facto communication theory for the internet and social media speech within Western democracies. ${ }^{27}$ This is because 'cyberspace is founded on

18 Abrams v United States 250 US 616 (1919), 630-1; see also Gitlow v New York 268 US 652 (1925), 673 per Justice Holmes.

19 E Barendt, 'The First Amendment and the media' in I Loveland (ed), Importing the First Amendment: Freedom of Speech and Expression in Britain, Europe and the USA (Hart 1998) 29-50, 43. See also, F Schauer, 'The political incidence of the free speech principle' (1993) 64 University of Colorado Law Review 935, 949-52.

20 Siebert et al (n 16).

21 The Royal Commission on the Press 1947-1949 was formed at the instigation of the National Union of Journalists. It was established 'with the object of furthering the free expression of opinion through the Press and the greatest possible accuracy in the presentation of news, to inquire into the control, management and censorship of the newspaper and periodical Press and the news agencies, including the financial structure and the monopolistic tendencies in control, and to make recommendations thereon'.

22 R Hutchins, Commission on Freedom of the Press, A Free and Responsible Press (University of Chicago Press 1947). The Commission was set up in 1942 and reported in 1947. Its aim was to examine areas and circumstances under which the press of the United States is succeeding or failing; to discover where freedom of expression is or is not limited, whether by government censorship pressure from readers or advertisers or the unwisdom of its proprietors or the timidity of its management'. According to McQuail, it was created in 'response to widespread criticism of the American newspaper press, especially because of its sensationalism and commercialism, but also its political imbalance and monopoly tendencies'. See D McQuail, McQuail's Mass Communication Theory 5th edn (Sage 2005) 170-1.

23 McQuail (n 22); Weiss (n 13) 577; Baran and Davis (n 3) 72-4; D Davis, 'News and politics' in D Swanson and D Nimmo (eds), New Directions in Political Communication (Sage 1990); J McIntyre, 'Repositioning a landmark: the Hutchins Commission and freedom of the press' (1987) 4 Critical Studies in Mass Communication 95-135; Siebert et al (n 16), ch 3.

24 C Christians, J Ferre and P Fackler, Good News: Social Ethics and the Press (Oxford University Press 1993$) 38$.

25 See Nemes (n 6) fns 6 and 7.

26 L Dahlberg, 'Cyber-libertarianism 2.0: a discourse theory/critical political economy examination' (2010) 6(3) Cultural Politics 331-56, 332-3.

27 Ibid. Weiss (n 13) 579. 
the primacy of individual liberty' 28 and, as a result, there now exists a 'normative assumption that all nation-states should adopt a libertarian orientation toward their oversight of new media'. ${ }^{29}$ As a consequence, largely due to the influence of the argument from truth and, in particular, the marketplace of ideas, libertarianism remains a dominant communication theory, not just in respect of US free speech jurisprudence, ${ }^{30}$ but also in relation to the underlying principles of the Fourth Estate and, significantly, in the context of online and social media speech. ${ }^{31}$

This section has established libertarianism's dominant position as a free speech communication theory. The following section will argue that, although this position may fit with the perceived ethos of The Circle and, in reality, cyber-libertarians and social media platforms such as Facebook, as a normative framework it is idealistic as opposed to being realistic. It will reject the theory, based on its unsuitability for twenty-firstcentury free speech and the modern media. This leads in to the discussion at Section 4 which sets out why the social responsibility model is better suited to this task. Ultimately, it will be argued that it provides a more appropriate normative basis for the argument from democratic self-governance that is an ideal philosophical foundation for free speech and the modern media.

\section{Rejecting libertarianism}

Justification for the protection of freedom of expression ${ }^{32}$ and media freedom is underpinned by four philosophical theories. These are: (i) the argument from truth; (ii) the marketplace of ideas; 33 (iii) the argument from self-fulfilment; and (iv) the argument from democratic self-governance. This philosophical foundation is apparent, to varying degrees, within contemporary domestic jurisprudence and that of the European Court of Human Rights (ECtHR). ${ }^{34}$ For instance, the House of Lords recognised the existence of

28 M Kapor, 'Where is the digital highway really going?' (1993) 1(3) Wired 53-9.

29 Weiss (n 13) 579.

30 Barendt (n 19) 43.

31 Dahlberg (31) 332-3.

32 As stated by Fenwick and Phillipson, freedom of expression is regarded as being one of the most fundamental rights. See H Fenwick and G Phillipson, Media Freedom under the Human Rights Act (Oxford University Press 2006) 12.

33 This theory was formulated by Justice Oliver Wendell Holmes in Abrams v United States (1919) 616, 630-1. As can be seen below, in $R v$ Secretary of State for the Home Department, ex parte Simms [2000] 2 AC 115, 126, Lord Steyn treated Mill's argument from truth and Justice Holmes' marketplace of ideas as interchangeable. This view is supported by a number of commentators, including Nicol, Millar and Sharland (see A Nicol QC, G Millar QC and A Sharland, Media Law and Human Rights 2nd edn (Oxford University Press 2009) 2-3 [1.05]) and Schauer (see F Schauer, Free Speech: A Philosophical Enquiry (Cambridge University Press 1982) 15-16), who treat the marketplace of ideas as simply a development of the argument from truth. However, in line with commentators such as Wragg (P Wragg, 'Mill's dead dogma: the value of truth to free speech jurisprudence' (2013) (April) Public Law 363-85, 368-9), Blasi (V Blasi, 'Reading Holmes through the Lens of Schauer' (1997) 72(5) Notre Dame Law Review 1343, 1355) and Barendt (E Barendt, Freedom of Speech 2nd edn (Oxford University Press 2005) 13), this thesis treats the theories as distinct.

34 According to Fenwick and Phillipson, in Handyside v UK (1976) 1 EHRR 737 the ECtHR referred, at least implicitly, to these theories, when it stated, at [49]: 'Freedom of expression constitutes one of the essential foundations of such a society, one of the basic conditions for its progress and for the development of every man.' However, Fenwick and Phillipson go on to observe that although freedom of expression can be defended on all of these rationales, only the argument from democratic self-governance has been prominently employed by the ECtHR. This is discussed in more detail below at section 3.1: See Fenwick and Phillipson (n 32) 707-10; P Wragg, 'A freedom to criticise? evaluating the public interest in celebrity gossip after Mosley and Terry' (2010) 2(2) Journal of Media Law 295-320, 318. 
all of these rationales in $R v$ Secretary of State for the Home Department, exparte Simms, ${ }^{35}$ where Lord Steyn stated the often-repeated passage ${ }^{36}$ that freedom of expression 'serves a number of broad objectives'. ${ }^{37}$

This section will demonstrate why the arguments from truth and the marketplace of ideas are ill suited to support modern free speech. This analysis will defend the proposition set out in the previous section that, despite its dominance over free speech jurisprudence, libertarianism does not provide an appropriate normative framework. This leads into Section 4 that argues that the social responsibility model is better suited to this task.

\subsection{THE ARGUMENT FROM TRUTH}

The argument from truth is located in Mill's nineteenth-century essay Of the Liberty of Thought and Discussion. ${ }^{38}$ The overall thrust of Mill's argument is that truth is most likely to emerge from totally uninhibited freedom of thought and almost absolute freedom of expression. ${ }^{39}$ Consequently, thought and discussion protects individual liberty from its predominant threat, ${ }^{40}$ which is not 'political oppression', ${ }^{41}$ but 'social tyranny', ${ }^{42}$

The argument has four facets. Firstly, the state would expose its own fallibility if it suppresses opinion on account of that opinion's perceived falsity as, in fact, it may be true. ${ }^{43}$ Secondly, even if the suppressed opinion is objectively false, it has some value, as it may (and in Mill's opinion very commonly does) contain an element of truth. ${ }^{44}$ Thirdly, since the dominant opinion on any given subject is rarely, or never, the whole truth, what remains will only appear as a result of the collision of adverse opinions. ${ }^{45}$ Finally, notwithstanding the third facet, even if the received opinion is not only true, but the entire truth, unless it is rigorously discussed and debated, it will not carry the same weight, as the rationale behind it may not be fully and accurately comprehended. ${ }^{46}$ Consequently, unless opinions can be frequently and freely challenged, by forcing those holding them to defend their views, the very meaning and essence of that true belief may, itself, be weakened, become ineffective, or even lost. ${ }^{47}$ In Mill's words, the true belief: 'will be held as a dead dogma, not a living truth'. ${ }^{48}$

Despite Schauer's argument that the desirability of truth within society is almost universally accepted, ${ }^{49}$ and the fact that this view seems to correlate with Jacob LJ's obiter

35 [2000] 2 AC 115.

36 Lord Steyn's judgment has been referred to numerous times within domestic jurisprudence. For a recent example, see: $\mathrm{R}$ (on the application of Lord Carlisle of Berriew QC and others) $v$ Secretary of State for the Home Department [2014] UKSC 60, per Lord Kerr at [164].

37 Ibid [126].

38 J Mill, On Liberty and Other Essays (Oxford University Press 1991); J Mill, On Liberty, Essays on Politics and Society, in J M Robson (ed), Collected Works of John Stuart Mill (University of Toronto Press 1977). Other Millian essays are of importance to the theory. When required, they are cited in the footnotes.

39 Mill, On Liberty in Robson (ed) (n 38) 225-6; Wragg (n 33) 365; Fenwick and Phillipson (n 32 ) 14.

40 Mill, On Liberty in Robson (ed) (n 38) 229.

41 Ibid 220.

42 Ibid.

43 See generally Barendt (n 33) 8; Mill, On Liberty in Robson (ed) (n 38) 258.

44 Mill, On Liberty in Robson (ed) (n 38) 229.

45 Ibid 252, 258.

46 Ibid 258.

47 Ibid 258; See also Wragg (n 33) 365.

48 Ibid 243, 258.

49 Schauer (n 33) 17; see also J Feinberg, Social Philosophy (Prentice-Hall 1973) 26. 
dicta in L'Oreal $S A v$ Bellure $N V^{50}$ that, pursuant to various international laws, 51 'the right to tell - and to hear - the truth has high international recognition', 52 the assumption derived from the argument that freedom of expression leads to truth can be attacked on a number of fronts. ${ }^{53}$ Firstly, there is not necessarily a causal link between freedom of expression and the discovery of truth. ${ }^{54}$ This is particularly pertinent with regard to the modern media, where, via mediums such as social media and the internet, anybody can express opinions or views, or disseminate information. Consequently, the internet and social media in particular are saturated with information that is inaccurate, misleading or untrue. This issue is animated by the 'fake news' phenomenon, ${ }^{55}$ which has led to social media platforms being asked to deal with the proliferation of fake news on their sites, ${ }^{56}$ and the recent Cambridge Analytica scandal. In respect of the former, Facebook, in particular, was the subject of strong criticism in the wake of the US election. ${ }^{57}$ This resulted in the platform announcing that it will be partnering with a third-party factchecking organisation to deal with the challenge of fake news. ${ }^{58}$ Arguably, the issue with fake news, and Facebook's response, betrays a deeper problem for social-networking platforms: this measure (partnering with a fact-checking organisation) clearly runs counter to libertarian ideology yet, at the same time, Facebook is trying to maintain a grip on libertarian values, demonstrated by its reiteration of its commitment to 'giving people a voice' and that it 'cannot become an arbiter of truth'. ${ }^{59}$ Thus, social media platforms, such as Facebook, are struggling to come to terms with a conflict between the reality of online speech and the libertarian values upon which they, as organisations, were originally founded. ${ }^{60}$ In other words, libertarianism is not compatible with what they have become. In the same vein, the fact that Cambridge Analytica harvested over 50 million user profiles without Facebook's permission and manufactured sex scandals and fake news to influence

50 [2010] EWCA Civ 535.

51 Article 19 Universal Declaration of Human Rights; Article 19(2) International Covenant on Civil and Political Rights; Article 10(1) ECHR; Article 11(1) Charter of the Fundamental Rights of the European Union: [2010] EWCA Civ 535, [10].

52 [2010] EWCA Civ 535, [10].

53 For commentary criticising the argument from truth in relation to pornography, see C MacKinnon, Feminism Unmodified (Cambridge University Press 1987) 166; Fenwick and Phillipson (n 32) 309-407.

54 Schauer (n 33) 15.

55 Fake news is discussed in more detail in Section 3.2 in relation to the marketplace of ideas.

56 E Klaris and A Bedat, 'With the threat of fake news, will social media platforms become [like] media companies and forsake legal protections?' (Inforrm's Blog, 21 December 2016) <https://inforrm.wordpress.com/2016/12/21/with-the-threat-of-fake-news-will-social-media-platformsbecome-more-media-companies-and-forsake-legal-protections-ed-klaris-and-alexia-bedat $>$.

57 See generally A Hunt and M Gertzkow, 'Social media and fake news in the 2016 election' (2017) 31(2) Journal of Economic Perspectives 211-36; O Solon, '2016: The year Facebook became the bad guy' The Guardian (London, 12 December 2018) <www.theguardian.com/technology/2016/dec/12/facebook-2016-problemsfake-news-censorship>.

58 Adam Mosseri, 'Addressing hoaxes and fake news' (Facebook Newsroom, 15 December 2017) <https://newsroom.fb.com/news/2016/12/news-feed-fyi-addressing-hoaxes-and-fake-news>.

59 Ibid.

60 Incidentally, Germany has recently adopted a new social media law known as NetzG. Amongst other things, this new regulatory regime requires platform providers, such as Facebook, to delete or block illegal content (for example, if it is defamatory, depicts violence or incites hatred). S Thiel, 'The new German social media law: a risk worth taking? An extended look' (Inforrm's Blog, 20 February 2018) <https://inforrm.org/2018/02/20/the-new-german-social-media-law-a-risk-worth-taking-an-extendedlook-stefan-theil>. 
voters in elections around the world ${ }^{61}$ is even more damning of libertarian ideology. The relative ease with which the firm breached Facebook's data security enabled it to essentially hijack democracy, demonstrating that the philosophical rationales underpinning libertarianism, in the form of the argument from truth and marketplace of ideas, are fundamentally flawed and unrealistic, particularly in the context of social media speech.

Secondly, despite Jacob LJ's dicta, there is no right to truth per se. ${ }^{62}$ Further, contrary to Schauer's statement, arguably the dissemination of truth is not always a good thing. In some situations, the protection of other, countervailing, values should take precedent. Ironically, this is illustrated by the international instruments referred to by Jacob LJ in L'Oreal. Taking the European Convention on Human Rights (ECHR) as an example, Article 10(1) is qualified by Article 10(2), which enables expression, and therefore both truths and untruths, to be legitimately withheld on grounds of, inter alia, health or morals, national security, public safety, protecting the reputation and honour of private individuals, the prevention of disorder or crime, and breach of confidence. Within the context of online and social media speech, the revenge porn phenomenon illustrates this dichotomy. In the UK, this offence, which exists by virtue of $\mathrm{s} 33$ of the Criminal Justice and Courts Act 2015, was essentially created to combat individuals sharing, via text messages and social media, sexually explicit content of an ex-partner without that person's permission. ${ }^{63}$ Although the explicit pictures, videos and accompanying text may well be 'true', the dissemination of this content could, clearly, harm the victim's health and morals, their reputation and honour and be a misuse of private information. ${ }^{64}$ Thus, as Barendt argues: '[i]t is not inconsistent to defend a ban on the publication of propositions on the ground that their propagation would seriously damage society, while conceding that they might be true'. ${ }^{65}$

Finally, a further argument that undermines the argument from truth as a rationale to defend free speech claims relates to its lack of application in ECtHR case law; an argument that, incidentally, applies equally to the marketplace of ideas. Strasbourg jurisprudence is most closely aligned with the argument from democratic self-governance, which the ECtHR has made clear is at the core of Article 10 ECHR. ${ }^{66}$ Of course, the UK's courts are able to develop the concept of free speech domestically, so as to provide for a right that encapsulates the broader arguments for freedom of expression found in the argument from truth, the marketplace of ideas and the argument from selffulfilment. ${ }^{67}$ Indeed, as illustrated by the judgments of Lord Steyn and Jacob LJ in $R v$ Secretary of State for the Home Department, ex parte Simms ${ }^{68}$ and L'Oreal ${ }^{69}$ respectively, the

61 P Greenfield, 'The Cambridge Analytica files: the story so far' The Guardian (London, 26 March 2018) <www.theguardian.com/news/2018/mar/26/the-cambridge-analytica-files-the-story-so-far accessed>.

62 Wragg (n 33) 372.

63 For further analysis, see P Coe, 'The social media paradox: an intersection with freedom of expression and the criminal law' (2015) 24(1) Information and Communications Technology Law 16-40, 13-14.

64 Prior to the Criminal Justice and Courts Act 2015 coming into force, a number of criminal offences and civil causes of action were applied to revenge porn. See ibid 13-14.

65 Barendt (n 33) 8.

66 Lingens v Austria (1986) 8 EHRR 407; Jersild v Denmark (1995) 19 EHRR 1; L Wildhaber, 'The right to offend, shock or disturb? Aspects of freedom of expression under the European Convention on Human Rights' (2001) 36 Irish Jurist 17; Wragg (n 34) 314.

67 Wragg (n 34) 314.

68 See above (n 35).

69 See above (n 50). 
argument from truth has been employed domestically. ${ }^{70}$ However, in conflict with these judgments, as Wragg observes, the House of Lords consistently interpreted the obligation imposed on judges to take Strasbourg jurisprudence into account in domestic proceedings, pursuant to s 2 of the Human Rights Act 1998, strictly, meaning that the domestic development of the concept of free speech in this way is hard to justify. ${ }^{71}$ For instance, in $\mathrm{R}$ (on the application of Ullah) $v$ Special Adjudicator ${ }^{72}$ Lord Bingham stated that the 'duty of the national courts is to keep pace with the Strasbourg jurisprudence as it evolves over time: no more, but certainly no less'. ${ }^{73}$ Consequently, domestic jurisprudence should 'mirror' the jurisprudence of the ECtHR. ${ }^{74}$ According to Lord Bingham in Ullah failure to follow 'clear and constant' Strasbourg jurisprudence would be unlawful under s 6(1) Human Rights Act 1998,75 unless there are 'special circumstances ${ }^{76}$ that justify departure from that approach. ${ }^{77}$ Despite Lord Bingham's judgment in Ullah being the subject of both judicial ${ }^{78}$ and academic $^{79}$ criticism, the mirror principle remains in place. Thus, unless is can be persuasively argued that such 'special circumstances' exist, then surely the philosophical argument that must be applied to domestic case law, in line with Strasbourg jurisprudence, is the argument from democratic self-governance as opposed to the inherently libertarian argument from truth and the marketplace of ideas.

\subsection{The MARKETPLACE OF IDEAS}

In Abrams $v$ United States ${ }^{80}$ Justice Holmes laid down the marketplace of ideas theory by asserting that: 'the best test of truth is the power of the thought to get itself accepted in the competition of the market'. ${ }^{81}$ It dictates that an open and unregulated market, which allows for ideas to be traded through the free expression of all opinions, is most likely to

70 See also $\mathrm{R}$ (on the application of Animal Defenders International) $v$ Secretary of State for Culture, Media and Sport [2008] UKHL 15. However, as stated by Wragg, arguably the argument from democratic self-governance could also have been applied to protect free speech in each of these cases: Wragg (n 34) 318.

71 Wragg (n 34) 314.

72 [2004] 2 AC 323.

73 Ibid 350 .

$74 \mathrm{R}$ (on the application of Quark Fishing Ltd) $v$ Secretary of State for Foreign and Commonwealth Affairs [2006] 1 AC 529, [34] per Lord Nicholls. See also J Lewis, 'The European ceiling on human rights' (2007) Public Law 720; Wragg (n 34) 314.

75 S 6(1) states: ' $[1]$ t is unlawful for a public authority to act in a way which is incompatible with a Convention right'; pursuant to s 6(3) the definition of 'public authority' includes the courts.

76 It is unclear what amounts to 'special circumstances'. See Wragg (n 34) 314.

77 Wragg (n 34) 314.

78 In $\mathrm{R}$ (on the application of Children's Rights Alliance for England) v Secretary of State for Justice [2013] EWCA Civ 34, [62]-[64], Law LJ stated that: 'I hope the Ullah principle may be revisited. There is a great deal to be gained from the development of a municipal jurisprudence of the Convention Rights, which the Strasbourg court should respect out of its own doctrine of the margin of appreciation, and which would be perfectly consistent with our duty to take account of (not to follow) the Strasbourg cases.'

79 R Masterman, "Taking the Strasbourg jurisprudence into account: developing a "municipal" law of human rights under the Human Rights Act (2005) 54 International and Comparative Law Quarterly 907; J Lewis, 'The European Ceiling on Human Rights' (2007) Public Law 720.

80250 US 616 (1919).

81 Ibid 630-1; see also Gitlow v New York 268 US 652 (1925), 673 per Justice Holmes. Subsequently, Holmes J's judgment garnered support from other influential judges, including: Justice Brandeis in Whitney v California 274 US 357 (1927), 375-8; Justice Hand in United States v Dennis 181 F2d 201 (2d Cir 1950) and International Brotherhood of Electrical Workers v NLRB 181 F2d 34 (2d Cir 1950); and Justice Frankfurter in Dennis v United States 341 US 494 (1951), 546-53 who observed that: 'the history of civilization is in considerable measure the displacement of error which once held sway as official truth by beliefs which in turn have yielded other truths. Therefore, of man to search for truth ought not be fettered, no matter what orthodoxies he may challenge.' 
lead to the truth and, consequently, increased knowledge. ${ }^{82}$ Hence, the examination of an opinion within the 'marketplace' subjects it to a test that is more reliable than individual or governmental appraisal. 83

Herein lies an initial problem with the theory: it is, in essence, a variation of a fundamental principle of capitalism - namely the notion of a self-regulating consumer marketplace. Consequently, it is open to both economic and democratic interpretations, ${ }^{84}$ which will be considered in turn.

The eighteenth-century economist Adam Smith formulated the principle of the 'invisible hand', or laissez-faire doctrine, guiding free consumer markets. Pursuant to this principle, there is no need for government regulation of markets, as an open and unregulated marketplace should regulate itself. Echoing Milton's self-righting process, if one manufacturer charges too much for a product, or produces an inferior product, competitors will either charge less or produce a higher quality product to attract buyers. Thus, government interference is not required to protect consumers or to force manufacturers to meet consumer needs. ${ }^{85}$ According to the theory, Smith's principle should be applied to the media; that is, if ideas are 'traded' freely within society, the correct or best ideas will, eventually, prevail. ${ }^{86}$

However, there are considerable difficulties in applying this logic to the modern media ${ }^{87}$ and, in particular, online speech. Media content is far less tangible than other consumer products. ${ }^{88}$ As a result, and in contrast to the consumer marketplace, the perceived meaning of individual media messages can vary depending on the respective recipient. Taking this a step further, the medium through which the information is communicated can also influence not only the communication's perceived meaning, but also the impact that it has on its intended and, potentially, non-intended audience. This point is illustrated by jurisprudence emanating from both the ECtHR and the US Supreme Court relating to the regulation of different forms of media. ${ }^{89}$ In Jersild $v$ Denmark, ${ }^{90}$ in the context of broadcasting, the ECtHR stated:

... the potential impact of the medium concerned is an important factor and it is commonly acknowledged that the audiovisual media have often a much more immediate and powerful effect than the print media ... conveying through images meanings which the print media are not able to impart. ${ }^{91}$

The Supreme Court has also acknowledged the significance of a medium in respect of the influence it can have on recipients of information. In Burstyn $v$ Wilson, ${ }^{92}$ which

82 See generally J Oster, 'Theory and doctrine of "media freedom" as a legal concept' (2013) 5(1) Journal of Media Law 57-78, 70; J Alonzo, 'Restoring the ideal marketplace: how recognizing bloggers as journalists can save the press' (2006) 9 New York University Journal of Legislation and Public Policy 751, 762.

83 Schauer (n 33) 16; see also Alonzo (n 82) 762.

84 P Napoli, 'The marketplace of ideas metaphor in communications regulation' (1999) 49) Journal of Communication 151-69, 151-2.

85 Adam Smith, The Wealth of Nations, A Skinner (ed) (Penguin 1982). See also Weiss (n 13) 577; Baran and Davis (n 3) 67.

86 Baran and Davis (n 3).

87 Ibid.

88 Ibid.

89 See generally D Mac Síthigh, Medium Law (Routledge 2018) 24-8; M Feintuck and M Varney, Media Regulation, Public Interest and the Law 2nd edn (Edinburgh University Press 2006) 81.

90 (1995) 19 EHRR 1.

91 Ibid [31].

92 (1952) 343 US 495. 
concerned cinema regulation, the court noted how a medium 'present(s) its own particular problems'. ${ }^{93}$ Similarly, in Metromedia $v$ City of San Diego, ${ }^{94}$ a case relating to billboard regulation, the court stated that each method of communication is a law unto itself' and, consequently, the law must respond to differences between media, in terms of their 'natures, values, abuses and dangers'. ${ }^{95}$ In FCC v Pacifica Foundation, ${ }^{96}$ which related to television broadcasting regulation, the court recognised television's immediacy, accessibility and its peculiarly pervasive and intrusive potential. ${ }^{97}$ Similarly, in Reno $v$ American Civil Liberties Union' 98 the court was of the opinion that 'the Internet is not as invasive as radio or television'. ${ }^{99}$ In coming to this decision, the court relied upon the finding of the District Court that:

Communications over the Internet do not invade an individual's home or appear on one's computer screen unbidden. Users seldom encounter content by accident ... [a]lmost all sexually explicit images are preceded by warnings as to the content .. . odds are slim that a user would come across a sexually explicit sight by accident. ${ }^{100}$

This decision is indicative of the pace at which online and social media communication has developed, as the findings upon which the decision is based are arguably at odds with current online expression and are without doubt diametrically opposed to The Circle's, albeit fictional, vision of the world. Internet communications, in particular those transmitted via social media, can be invasive. To an extent this may be 'allowed' by the user of the social media platform, by virtue of registering with the platform and joining particular communities. However, users are still subject to 'unbidden' messages regularly appearing on their mobile telephone, tablet and laptop screens. ${ }^{101}$ Further, the availability of sexually explicit content has been proliferated by social media and is synonymous with platforms such as WhatsApp and Snapchat, as demonstrated by the 'revenge porn' phenomenon. ${ }^{102}$

Although these cases pre-date the advent of social media and citizen journalism, the concerns espoused by the ECtHR and the Supreme Court are almost prophetic, as they are equally as applicable, if not more pertinent, to online and social media expression. As acknowledged by a number of scholars, the internet and social media have facilitated an audience-producer convergence, ${ }^{103}$ which has allowed for the circumvention of normal editorial and production processes. ${ }^{104}$ Whilst this can enable excellent citizen journalism, it can also breed, through the speech it conveys, its own 'abuses and dangers'. ${ }^{105}$ Because

93 Ibid 503.

94 (1981) 453 US 490.

95 Ibid 501.

96 (1978) 438 US 726.

97 Ibid 727.

98521 US 844 (1997).

99 Ibid 869.

100 American Civil Liberties Union v Reno, 929 F Supp 824 (ED Pa, 1996) (finding 88).

101 For detailed analysis of how the economic constructs of social media has influenced this issue, see José van Dijck, The Culture of Connectivity (Oxford University Press 2013) 163-76.

102 Coe (n 63) 28-9. See generally Brian Leiter, 'Cleaning cyber-cesspools: Google and free speech' in Saul Levmore and Martha C Nussbaum (eds), The Offensive Internet (Harvard University Press 2010) 155.

103 J Rowbottom, 'To rant, vent and converse: protecting low level digital speech' (2012) 71(2) Cambridge Law Journal 355-83, 365; A Bruns, Blogs, Wikipedia, Second Life and Beyond: From Production to Produsage (Peter Lang Publishing 2008).

104 Coe (n 11) 32.

105 Ibid. 49. 
social media is arguably more 'immediate, pervasive and accessible' to individuals than even television broadcasting, its messages have a potentially greater impact than any other medium.

Turning now to the democratic interpretation of the theory, it has been suggested that discovering truth is dependent upon unregulated competition in the actual, as opposed to ideal, marketplace. ${ }^{106}$ It has also been said that the theory dictates that the ideas that emanate from the competitive market are the truth, leaving nothing more to be said. ${ }^{107}$ Oster relies on this rationale to support his view that, because of the media's power and ability to communicate via multiple channels, the theory requires that the media should be subject to protection and only minimal restriction. ${ }^{108}$ This is because this 'privilege' for journalists encourages the dissemination of more information that, sequentially, generates more valuable, truthful information. However, it is submitted that this reasoning is flawed, as it is the very reason used by Oster to support his approach that renders the theory unsuitable to that which it has been applied. Indeed, according to Barendt, whatever interpretation is adopted, the theory 'rests on shaky grounds', ${ }^{109}$ which 'appear particularly infirm in the context of mass media communications' 110 for reasons that can be applied to both traditional and social media. ${ }^{111}$

Firstly, if the assertion that one statement is stronger than another (whether these statements are communicated via a social media platform or by the traditional media) cannot be intellectually supported and defended, the notion of truth loses its integrity, ${ }^{112}$ as history demonstrates: falsehood frequently triumphs over truth, to the detriment of society. ${ }^{113}$ Secondly, in line with Habermas' concept of 'discourse', which aims at reaching a rationally motivated consensus and is based on the assumption of the prevalence of reason, ${ }^{114}$ the theory assumes that recipients of the communication consider what they read or view within the context of the marketplace rationally; deciding whether to accept or reject it, based on whether it will improve their lifestyle, and society generally. ${ }^{115}$ As both Schauer and Barendt suggest, this assumption is unrealistic. ${ }^{116}$ Both criticisms are pertinent to social media speech and citizen journalism, but also apply

106 B Williams, Truth and Truthfulness (Princeton University Press 2002) 214-15; See also Barendt (n 33) 12.

107 Barendt (n 33) 12.

108 Oster (n 82) 70-1; J S Nestler, 'The underprivileged profession: the case for Supreme Court recognition of the journalist's privilege' (2005) 154 University of Pennsylvania Law Review 201, 211; A Koltay, 'The concept of media freedom today: new media, new editors and the traditional approach of the law' (2015) 7(1) Journal of Media Law 36-64; A Koltay, 'What is press freedom now? New media, gatekeepers and the old principles of the law' in A Koltay (ed), Comparative Perspectives on the Fundamental Freedom of Expression (Wolters Kluwer 2015) 55-87.

109 Barendt (n 33) 12. See also Barendt (n 19).

110 Barendt (n 19).

111 For a comprehensive critique of the theory, see Barendt (n 33) 12.

112 Ibid.

113 R Abel, Speech and Respect (Stevens \& Sons 1994) 48; D Milo, Defamation and Freedom of Speech (Oxford University Press 2008) 57.

114 J Habermas, The Structural Transformation of the Public Sphere (Polity Press 1962); The Theory of Communicative Action, vol 1: Reason and the Rationalization of Society (Beacon Press 1984) 25, 39, 99; The Theory of Communicative Action, vol. 2: Lifeworld and System: A Critique of Functionalist Reason (Beacon Press 1987) 120, 319; J Oster, Media Freedom as a Fundamental Right (Cambridge University Press 2015) 29-31.

115 J Weinberg, 'Broadcasting and speech' (1993) 81 California Law Review 1103; S Ingber, 'The marketplace of ideas: a legitimizing myth' [1984] Duke Law Journal 1; J Skorupski, John Stuart Mill (Routledge 1991) 371-2.

116 F Schauer, 'Free speech in a world of private power' in T Campbell and W Sadurski (eds), Freedom of Communication (Dartmouth 1994) 6; Barendt (n 33) 12. See also A Kenyon, 'Assuming free speech' (2014) 77(3) Modern Law Review 379-408, 382. 
equally to the traditional media using social media as a source of news. For the reasons discussed in the following paragraphs, it is submitted that this basis of rationality makes a fallacy of the marketplace of ideas theory.

The first observation to be made about rationality is that social media proliferates a huge amount of information that is poorly researched or simply untrue, yet has the potential to, and very often does, emerge as the dominant 'view', 117 regardless of the detrimental impact this may have on society. ${ }^{118}$ In turn, the traditional media using social media as a source of news may regurgitate the same information. Arguably, this issue is amplified by the ubiquity of anonymity and pseudonymity on the internet and social media, making it hard, if not impossible, for readers to accurately and rationally assess the veracity of the speaker. ${ }^{119}$ Thus, in reality, in a marketplace that contains true and untrue or misleading information in at least equal proportions, some of which may be published anonymously or under a pseudonym, it may be impossible for recipients of the communication to make a rational assessment of what they have read, viewed or listened to.

This point leads on to a second observation, based on cognitive psychology research that, although pre-dating the advent of social media, is particularly relevant to social media speech, and is therefore worthy of consideration. In order to deal with the endless flow of information we are subjected to on a daily basis we try to fit each new piece of information into a set of pre-existing cognitive structures, or schemas, that provide 'simplified mental models' of the world. ${ }^{120}$ Processing new ideas and information this way creates problems when people encounter information that cannot be processed in this manner, as they reject information that conflicts with their schemas. ${ }^{121}$ According to scholars such as Graber, McGuire and Peffley et al, in these circumstances, people are pre-disposed to deny the validity of the new information and, instead, reinterpret it so that it conforms to the schema within which they want the information to fit or, alternatively, they process it as an isolated exception. ${ }^{122}$ Therefore, as Fajer suggests, because people interpret ambiguous reality to accord with their schemas, they become self-reinforcing and, in turn, more powerful as they are repeatedly 'tested' but never disconfirmed. ${ }^{23}$ This is indicative of arguments suggesting that the mass media are better at reinforcing existing attitudes and beliefs than changing them, ${ }^{124}$ as we largely ignore information that we deem irrelevant to our existing schemas. ${ }^{125}$ As Weinberg states, once people 'make up their mind' and 'reach closure' on an issue, they tend to reject new information, regardless of whether it supports or conflicts with their views. ${ }^{126}$

117 This criticism reflects those levelled at Mill's theory above. In particular, Schauer's argument that there is not necessarily a causal link between freedom of expression and the discovery of truth. See Section 3.1 above.

118 See, for example, the point made about fake news and the Cambridge Analytica scandal in Section 3.1 above.

119 See generally P Coe, 'Anonymity and pseudonymity: free speech's problem children' (2018) Media and Arts Law Review 119, 173-200.

120 D Graber, Processing the News: How People Tame the Information Tide, 2nd edn (Guildford Publications 1988$) 31$.

121 Weinberg (n 133) 1159.

122 Graber (n 120) 174-7; W McGuire, 'Attitudes and attitude change' in G Lindzey and E Aronson (eds), Handbook of Social Psychology 3rd edn (Lawrence Elbaum Association 1986) 233, 275-6; M Peffley et al, 'Economic conditions and party competence: processes of belief revision' (1987) 49 Journal of Politics 100, 101.

123 M. Fajer, 'Can two real men eat quiche together? Storytelling, gender-role stereotypes and legal protection for lesbians and gay men' (1992) 46 University of Miami Law Review 511, 525.

124 L Jaffe, 'The editorial responsibility of the broadcaster: reflections on fairness and access' (1972) 85 Harvard Law Review 768, 769-70; Weinberg (n 133) 1160.

125 Graber (n 120) 186.

126 Weinberg (n 133) 1160. 
Conversely, people seek out and resonate with information that is compatible with their schemas and will, sequentially, 'support' this information. ${ }^{127}$ In Ingber's view, it is impossible to create a collective marketplace of unfettered discourse and discovery if we are constrained by our adherence to long-established mental patterns. ${ }^{128}$ This results in the 'packaging' of an argument determining how well it is received, as opposed to it being assessed on the merits of its 'contents'.129 Consequently, because our schemas influence what ideas and information, we are willing to accept 'people's social location ... control[s] the manner in which they perceive and understand the world'. ${ }^{130}$ This research has been described as having 'distressing implications for marketplace theory'; 131 it is submitted that it clearly reinforces the point that the marketplace of ideas' basis of rationality makes a fallacy of the theory; as to the extent that our schemas constrain how we react to new ideas and information, the way we think is not 'characterised by reason'. ${ }^{132}$ This observation is significant to social media which, due to the sheer amount of information it generates and the invasive way in which it can potentially disseminate it, arguably only serves to amplify how we process information using pre-existing schemas and, in doing so, makes the issue with rationality more acute. The fake news phenomenon and its association with social media 'filter bubbles' animate this. Filter bubbles are created by algorithms that filter our online experiences, effectively placing us in echo chambers of our own beliefs, ${ }^{133}$ which means we are more likely to interact with content which conforms with our pre-existing views ${ }^{134}$ and which, in turn, creates greater polarisation. Therefore, the more we interact with particular 'types' of information on social media, whether that be true or fake, the more of that particular 'type' of information we will be exposed to by virtue of the filter bubble. Thus, within the context of social media speech at least, as Weinberg declares: '[t]o the extent that our most basic views and values are relatively immune to rational argument, the marketplace metaphor seems pointless'. ${ }^{135}$

The third and final reason why the theory is flawed relates to truth discovery. Although this issue is particularly pertinent to the traditional media, it is also relevant to citizen journalism and social media. The theory's integrity is contingent upon the sincerity and truthfulness of the speaker, and therefore assumes that the marketplace contains expression that solely represents the views of the proponents of, for instance, publications or broadcasts, as opposed to being conveyed on the basis of restrictions such as editorial control, ownership, political bias or increased commercial revenue ${ }^{136}$ through

127 S Fiske and S Taylor, Social Cognition 2nd edn (Sage 1991) 218-20.

128 Ingber (n 155) 34-6; See also: F Schauer, 'Hohfeld's First Amendment' (2008) 76 George Washington Law Review 914, 924; Kenyon (n 116) 382.

129 C Baker, 'Scope of the First Amendment freedom of speech' (1978) 25 University of California Los Angeles Law Review 964, 976-77; Graber (n 120) 158-60, 261.

130 Baker (n 129) 967.

131 Weinberg (n 133) 1162.

132 Ibid.

133 See generally D Spohr, 'Fake news and ideological polarization: filter bubbles and selective exposure on social media' (2017) 34(3) Business Information Review 150-60; E Pariser, The Filter Bubble: What the Internet is Hiding from You (Penguin 2011).

134 N Stroud, 'Media use and political predispositions: revisiting the concept of selective exposure' (2008) 30 Political Behaviour 341-65.

135 Weinberg (n 133) 1162.

136 For example, in January 2015 Daily Telegraph journalists voiced their concerns over the newspaper allegedly discouraging them from writing unfavourable stories about advertising and commercial partners. Furthermore, the journalists provided examples to Newsnight of how commercial concerns impacted upon coverage given to China and Russia. See C Cook, 'More Telegraph writers voice concern' (BBC News, 19 February 2015) <www.bbc.co.uk/news/health-31529682>. 
advertising and/or sales. ${ }^{137}$ This may be true within the context of social media, where there are, in theory at least, fewer restrictions. Although, this is not always the case, as many bloggers may simply regurgitate false, bias or misleading information. ${ }^{138}$ In relation to the traditional media, this assumption is equally as unrealistic, for two reasons: firstly, many media outlets, particularly commercial ones, are driven by the restrictions set out above, to the detriment of investigative journalism. ${ }^{139}$ Indeed, as observed by Gibbons:

The liberal theory of the media appears to be influential, yet there is a countervailing view, supported by much evidence, that the media have a tendency to distort our understanding of the world ... The media devote a relatively small part of their content to public affairs ... preferring to emphasise entertainment more generally ... Furthermore, news may be managed to serve the media's interests, whether they are the proprietor's or the company's more broadly. ${ }^{140}$

Thus, as Kenyon states, there is a 'disjunction between ideas of political equality and economic communication markets'. ${ }^{141}$ These markets are inconsistent with democratic requirements as commercial media's orientations have primarily been to advertisers and to audiences as consumers. ${ }^{142}$ Consequently, research points towards there being a 'narrowness of political views within major media'. ${ }^{143}$ As Baker acknowledges, the market-based media cannot be expected to serve audiences well as citizens; ${ }^{144}$ secondly, as has been previously discussed, traditional media outlets use citizen journalists and social media generally as a source of news. Thus, in the same way that bloggers may regurgitate false or misleading information obtained, for instance, from the traditional media or other bloggers, the traditional media may do the same in respect of information obtained from social media. ${ }^{145}$

Ultimately, libertarianism is flawed as a normative paradigm as it is based on the unproven assertion that the product of the media marketplace, which is only one out of an infinite number of potential outcomes, gains a de facto privileged status as the 'truth'.146

137 Barendt (n 33) 12.

138 Indeed, as discussed below at Section 5.1, Curran, Fenton and Freedom observe that the internet and, it is submitted by extension, social media and citizen journalism, is not exempt from 'corporate dominance, market concentration, controlling gatekeepers, employee exploitation, manipulative rights management, economic exclusion through "tethered appliances" and encroachment upon the information commons.' J Curran, N Fenton and D Freedman, Misunderstanding the Internet (Routledge 2012) 180.

139 Barendt (n 33) 12; T Cook, Governing with the News: The News Media as a Political Institution 2nd edn (University of Chicago Press 2005) 168; T Gibbons, 'Fair play to all sides of the truth: controlling media distortions' (2009) 62(1) Current Legal Problems 286-315, 291; N Davies, Flat Earth News (Vintage Books 2009).

140 Gibbons (n 139). See also J Curran, 'Mediations of democracy' in J Curran and M Gurevitch (eds), Mass Media and Society 4th edn (Hodder Arnold 2005) 129.

141 Kenyon (116) 386.

142 Ibid; Gibbons (n 139) 290.

143 Kenyon (116) 387. See also the study by Toril Aalberg and James Curran et al which investigated the content of print and broadcast news and ordinary people's knowledge and understanding of matters of political and more general public interest: T Aalberg and J Curran (eds), How Media Inform Democracy: A Comparative Approach (Routledge 2012).

144 See generally C Baker, Media, Markets and Democracy (Cambridge University Press 2002).

145 Even before and at the dawn of the social media age, various studies showed that certain sources dominate the news: V Campbell, Information Age Journalism: Journalism in an International Context (Arnold 2004), ch 4; Goldsmiths Media Group, 'Media Organisations in Society: Central Issues' in J Curran (ed), Media Organisations in Society (Arnold 2000) 19-69, 34; P Schlesinger, Putting Reality' Together (Methuen 1978); Gibbons (n 139 ) 290.

146 G Wuliger, 'The moral universes of libertarian press theory' (1991) 8 Critical Studies in Media Communication 152-67, 156; Plaisance (n 14) 297. 
As Schwarzlose states, this creates the 'dilemma of libertarianism': in the marketplace of ideas 'is it truth that survives, or is whatever survives the truth?'147 Based on the arguments advanced in this section, it is submitted that libertarianism, as a normative paradigm founded upon philosophical doctrine such as the argument from truth and the marketplace of ideas, is unable to provide a suitably robust rejoinder to this 'dilemma', which clearly demonstrates that libertarian ideology is an inadequate normative framework for the modern media. The following sections will consider the social responsibility model as a more suitable basis for such a framework.

\section{Social responsibility theory and the argument from democratic self-governance: standards and norms of behaviour and discourse}

This section will argue that, by endorsing a two-tiered approach to media expression, the social responsibility theory, as underpinned by the argument from democratic selfgovernance, creates a more appropriate normative and philosophical framework for the modern media than libertarianism. The theory dictates that media freedom is distinct from personal freedom of expression, a view that correlates with the jurisprudence of the ECtHR. ${ }^{148}$ This distinction means that certain demands can be placed on media actors in performance of their duties over and above what would apply to individuals. Thus, as Leveson LJ acknowledges in his Inquiry into the Culture, Practices and Ethics of the Press, ${ }^{149}$ unlike individual expression, freedom of the press (and it is submitted, by extension, the wider media) is valued only instrumentally, as opposed to intrinsically, when it performs democratic functions with a view to developing commercially as a sector, such as informing the democratic process, and acting as a check and balance on political, corporate or individual power. ${ }^{150}$ This section will advance the notion that under this social responsibility/argument from democratic self-governance framework the enjoyment of media freedom is contingent upon the fulfilment of certain standards of behaviour and public discourse, or concomitant duties and responsibilities: namely the norms referred to in Sections 4.1 and 4.2 below. Specifically, Section 4.1 considers the first tier of the framework: behavioural norms associated with the social responsibility theory. Section 4.2 sets out the second tier: how these norms are complemented by the argument from democratic self-governance in respect of the type of speech the media conveys. This will lead in to a discussion at Section 5 on how the theory and the argument provide a more suitable framework for dealing with some of the issues identified in Section 3 that are created by libertarianism and, specifically, from which to 'hang' a regulatory regime.

\subsection{TIER ONE: SOCIAL RESPONSIBILITY THEORY AND BEHAVIOURAL NORMS}

Like libertarianism, the social responsibility theory is an Anglo-American concept. As stated in Section 2, the catalyst for the emergence of the theory was two reports commissioned on either side of the Atlantic in the 1940s: the Royal Commission on the

147 R Schwarzlose, 'The marketplace of ideas: a measure of free expression' (1989) 118 Journalism Monographs $1-41,8$.

148 See above (n 11). As is discussed in more detail below at Section 5.3 this also correlates with the influential evidence given by Baroness O’Neill to the Leveson Inquiry. O’Neill has long held the view that media freedom is normatively distinct to personal freedom of expression (Lord Justice Leveson, An Inquiry into the Culture, Practices and Ethics of the Press: Report (House of Common 780, 2012) 55, [3.7]). See <http://webarchive.nationalarchives.gov.uk/20140122145147/http://www.levesoninquiry.org.uk/wpcontent/uploads/2012/07/Witness-Statement-Of-Baroness-ONeil.pdf >.

149 Leveson (n 148).

150 Ibid 55, [4.1]-[4.5]. 
Press $^{151}$ in the UK and the Hutchins Commission report ${ }^{152}$ in the USA. The Commission's report was particularly influential in establishing this new communication paradigm. Accordingly, in Baker's view, it 'provides the most influential modern account of the goals of journalistic performance' and is virtually treated as the 'official Western view'. ${ }^{153}$ In simple terms the report laid down five requirements of media performance: firstly, to provide a truthful, comprehensive and intelligent account of the day's events in a context which gives them meaning, and to clearly distinguish fact from opinion; secondly, to be a forum for the exchange of comment and criticism by operating as common carriers of public discussion, even if this means disseminating views contrary to their own; thirdly, to project a representative picture of the constituent groups in society; fourthly, to be responsible for the presentation and clarification of the goals and values of society; and, fifthly, to provide full access to the day's intelligence. ${ }^{154}$

The Royal Commission and Hutchins Commission reports, and the eventual establishment of the theory, were born out of diminishing faith in libertarianism and the 'optimistic' notion that virtually absolute freedom and the self-righting process carried 'built-in correctives' for the media. ${ }^{155}$ Siebert et al distil the themes of criticism of the media at the time as follows: (i) it used its power for its own ends, with owners propagating their own opinions to their political and economic advantage at the expense of opposing views; (ii) it had been subservient to big business, with advertisers controlling editorial policies and content; (iii) it resisted social change; (iv) it was more willing to publish superficial and sensational stories than to publish 'significant' stories; (v) it had endangered public morals; (vi) it invaded the privacy of individuals without just cause; (vii) it was controlled by an elite socioeconomic class, meaning that access to the industry was difficult, which consequently endangered the free and open marketplace of ideas. ${ }^{156}$ This disillusionment gave rise to an extreme anti-libertarian movement that resulted in increased pressure on the UK and US governments to regulate the media. Within the Hutchins Commission itself there was a clear divide between those who held strong libertarian views and those who favoured some form of media regulation, due to, in their view, the fragility of the marketplace of ideas theory making the media vulnerable to subversion by anti-democratic forces. ${ }^{157}$ These proponents of regulation were guided by a philosophy of public communication developed by social researchers at the University of Chicago during the 1940s. ${ }^{158}$ In opposing the notion of the marketplace of ideas the Chicago School argued that unregulated mass media served the interests of large or socially dominant groups. To their mind, the protection of free speech was not the same as the provision of free speech. ${ }^{159}$ Therefore, they wanted government regulation to play an 'interventionary role' in order 'to provide enabling structures for a healthy

151 The Royal Commission on the Press 1947-1949.

152 Hutchins (n 22). The Commission was set up in 1942 and reported in 1947.

153 Baker (n 144) 154. Baker has also described it as 'the most important, semi-official, policy orientated study of the mass media in US history'. C Baker, Media Concentration and Democracy: Why Ownership Matters (Cambridge University Press 2007) 2.

154 Baker (n 153) 20-30.

155 Siebert et al (n 16) 77.

156 Ibid 78-9.

157 Baran and Davis (n 3) 73.

158 Ibid. See also V Pickard, America's Battle for Media Democracy: The Triumph of Corporate Libertarianism and the Future of Media Reform (Cambridge University Press 2015) 154.

159 Baran and Davis (n 3) 73. 
public sphere'. ${ }^{160}$ Despite the majority of the Commission having some sympathy with the ideas advanced by the School, it opposed any direct form of regulation, because it feared that this could act as a catalyst for official control of the media. ${ }^{161}$ Consequently, a compromise came in the form of the social responsibility theory, which was founded on faith placed in the media by the members of the Commission, who emphasised that the media needed to refocus its efforts on serving the public. ${ }^{162}$

Thus, the theory is based on the following rationale: unlike libertarianism, which dictates that free speech is absolute and, as a result, does not propagate duties and responsibilities that attach to the right to freedom of expression and media freedom, under social responsibility doctrine, freedom of speech carries concomitant responsibilities and obligations to society, employers and the market. ${ }^{163}$ If the media does not at least attempt to meet these behavioural norms then, as a consequence, it cannot benefit from the right to media freedom. The theory rests on the moral principle of justice, ${ }^{164}$ hence the right to free speech and media freedom must be balanced against the private rights of others and vital social interests: as beneficiaries of the right to media freedom, the media is obligated to continually strive to preserve democracy ${ }^{165}$ by fulfilling essential constitutional normative functions of mass communication that extend beyond the mere provision of a robust marketplace of ideas, ${ }^{166}$ including: (i) 'servicing the political system' by providing information, discussion and debate on public affairs; (ii) 'enlightening the public' so as to make it capable of democratic self-governance by disseminating information of public interest; and (iii) 'protecting the rights of the individual' by acting as the public watchdog. ${ }^{167}$ In fulfilling these functions the media must ensure that it: sets and maintains high professional standards of truth and balance and conduct; avoids the communication of material that may lead to or incite criminal activity; and refrain from offending minority or marginalised groups. ${ }^{168}$ Finally, at the heart of the theory is the requirement of the media to foster productive and creative 'Great Communities' by prioritising cultural pluralism by being a voice for all people, not just elite or dominant groups. ${ }^{169}$

160 V Pickard, 'Whether the giants should be slain or persuaded to be good: revisiting the Hutchins Commission and the role of media in a democratic society' (2010) 27 Critical Studies in Media Communication 391-411, 394.

161 See generally Davis (n 23) 95-135.

162 Baran and Davis (n 3) 72; J. Curran, 'Mass media and democracy: a reappraisal' in J Curran and M Gurevitch (eds), Mass Media and Society (Edward Arnold 1991) 98.

163 Siebert et al (n 16) 74.

164 Plaisance (n 14) 300.

165 Baran and Davis (n 3) 73.

166 Siebert et al (n 16) 74; Plaisance (n 14) 300.

167 Siebert et al (n 16) 74.

168 Weiss (n 13) 577.

169 Baran and Davis (n 3) 73. 


\subsection{TIER TWO: SOCIAL RESPONSIBILITY THEORY AND THE ARGUMENT FROM DEMOCRATIC SELF-GOVERNANCE - NORMS OF PUBLIC DISCOURSE}

Although the argument from democratic self-governance has been applied by the US Supreme Court and the House of Lords to defend free speech claims, ${ }^{170}$ it is most commonly associated with the jurisprudence of the ECtHR. ${ }^{171}$ As explained above in relation to the argument from truth, ${ }^{172}$ the ECtHR has consistently placed it at the core of its jurisprudence on Article $10^{173}$ and, as a result, pursuant to the 'mirror principle', it should, in theory at least, be the dominant philosophical foundation for free speech domestically. ${ }^{174}$ Regardless of how the argument has been treated jurisprudentially in the USA, by the ECtHR and by domestic courts, it is submitted that, along with the social responsibility paradigm, it is the best-suited philosophical argument to underpin the modern media. Indicative of the behavioural standard and norms underpinning social responsibility theory, set out in the previous section, the argument is based on the premise that the predominant purpose of freedom of expression is to protect the right of citizens to understand political matters in order to facilitate and enable societal engagement with the political and democratic process. ${ }^{175}$ Ultimately, an informed electorate is a prerequisite of democracy. Thus, the argument complements the social responsibility paradigm by setting norms, or parameters, for the type of speech the media can convey within the confines of media freedom.

According to Bork, speech regarding 'government behaviour, policy or personnel, whether . . . executive, legislative, judicial or administrative ${ }^{176}$ was the original subject that was perceived as being protected by the right to freedom of expression. ${ }^{177}$ However, the scope of this approach was seen as being overly restrictive. ${ }^{178}$ Consequently, Alexander Meiklejohn, with whom this argument is now primarily associated, ${ }^{179}$ argued for the substitution of political expression with the wider and less restrictive notion of 'public discussion', relating to any matter of public interest, as opposed to expression linked

170 For example, from the US Supreme Court see Whitney $v$ California 274 US 357 (1927) per Brandeis J at 375-8 (1927); Garrison v Louisiana 379 US 64, 74-5 (1964); C Estlund, 'Speech on matters of public concern: the perils of an emerging First Amendment category' (1990) 59(1) George Washington Law Review 1-54, 1. From the House of Lords, see R $v$ Secretary of State for the Home Department, ex parte Simms (n 33) per Lord Steyn at 126. See generally Barendt (n 33) 18.

171 For example, see Lingens v Austria (1986) A 103, [42]; Bladet Tromso and Stensaas v Norway (2000) 29 EHRR 125, [59]; Bergens Tidande v Norway (2001) 31 EHRR 16, [48]

172 See Section 3.1.

173 Lingens v Austria (1986) 8 EHRR 407; Jersild v Denmark (1995) 19 EHRR 1. See also L Wildhaber, "The right to offend, shock or disturb? Aspects of freedom of expression under the European Convention on Human Rights' (2001) 36 Irish Jurist 17; Wragg (n 34) 314.

174 See Section 3.1 for detailed discussion of the 'mirror principle'.

175 See generally Sir J Laws, 'Meiklejohn, the First Amendment and free speech in English law' in Loveland (n 19) 123-37; Nicol et al (n 33) 3 [1.06]; Barendt (n 33) 18.

176 R H Bork, 'Neutral principles and some First Amendment problems' (1971) 47 Indiana Law Journal 1, 27-8.

177 Oster (n 82) 69.

178 Ibid; Milo (n 113) 63-4; M R Chesterman, Freedom of Speech in Australian Law: A Delicate Plant (Ashgate Publishing 2000) 48; See also A Kenyon, Defamation and critique: political speech and New York. Times v Sullivan in Australia and England' (2001) 25 Melbourne University Law Review 522, 539; R Gilson and M Leopold, 'Restoring the "central meaning of the first amendment": absolute immunity for political libel' (1986) 90 Dickinson Law Review 559, 574.

179 Nicol et al (n 33) 3, [1.06]. 
purely to the casting of votes. ${ }^{180}$ Meiklejohn stated that public discussion is speech which impacts 'directly or indirectly, upon the issues with which voters have to deal [i.e.] to matters of public interest'. ${ }^{181}$ A result of this bifurcated interpretation of free speech is a two-tiered approach to expression: ${ }^{182}$ speech that is not in the public interest is not protected and is therefore open to restriction to protect the general welfare of society. ${ }^{183}$ In later writings, Meiklejohn clarified this wider view of 'public discussion', by stating that voting is merely the 'external expression of a wide and diverse number of activities by means of which citizens attempt to meet the responsibilities of making judgments'. ${ }^{184}$ Accordingly, education, philosophy and science, literature and the arts, and public discussions on public issues are activities that will educate citizens for self-government. ${ }^{185}$

This public interest requirement, pursuant to the social responsibility argument and argument from democratic self-governance framework, correlates with the jurisprudence of the US Supreme Court, and the UK Court of Appeal, House of Lords and Supreme Court which have all made consistent reference to it. As Oster observes, ${ }^{186}$ the courts have expressed this in a number of ways, including: 'public interest' or 'public concern';187 'of political, social or other concern to the community'; 188 'influences social relations and politics on a grand scale'; or is part of a 'debate about public affairs'; makes a 'contribution to the public debate'; stimulating 'political and social changes' ${ }^{189}$ Similarly, the ECtHR's jurisprudence provides rich precedent supporting the public interest requirement. It has regularly referred to 'matters of general public interest' and 'matters of public concern' within a variety of different circumstances. The principle has been applied to, amongst many other things: ${ }^{190}$ national and local level political speech and reporting; ${ }^{191}$ criticism of

180 A Meiklejohn, Political Freedom: The Constitutional Powers of the People (Oxford University Press 1960) 42; A Meiklejohn, 'The First Amendment is an absolute' [1961] Supreme Court Review 245, 255-7; Milo (n 113) 63-4; Oster (n 82) 69.

181 Meiklejohn, Political Freedom (n 180) 79.

182 An advocate of this approach is C R Sunstein. See generally C R Sunstein, Democracy and the Problem of Free Speech (The Free Press 1993); C R Sunstein, The Partial Constitution (Harvard University Press 1994).

183 Milo (n 113) 62-3.

184 Meiklejohn, 'The First Amendment' (n 180) 255.

185 Ibid 257, 263; For judicial application of this wider interpretation of the theory see, Reynolds $v$ Times Newspapers Limited [2001] 2 AC 127, (HL) per Lord Cooke at 220; Jameel v Wall Street Journal Europe Sprl [2007] 1 AC 359, (HL) per Baroness Hale at [158]. This wider view of public discussion advanced by Meiklejohn reflects the fact that the ECtHR has resisted defining the democratic process value in free speech narrowly; Wragg (n 34) 318. Indeed, the wide ambit afforded to the argument from democratic self-governance by the Strasbourg Court is demonstrated by jurisprudence consistently finding the democratic process value to be at stake in commercial expression cases. For example, see Krone Verlag GmbH \& Co KG v Austria (2006) 42 EHRR 28.

186 Oster (n 82) 74.

187 For example see Gertz v Robert Welch Inc 418 US 323, 246 (1974); Dun and Bradstreet Inc v Greenmoss Builders 472 US 749, 761 (1985); Hustler Magazine v Falwell 485 US 46, 50 (1988); Bartnicki v Vopper 532 US 514, 528, 5334 (2001); London Artists v Littler [1969] 2 QB 375, 391 (CA) (per Lord Denning); Reynolds v Times Newspapers Ltd (n 185) 205 (per Lord Nicholls); Jameel v Wall Street Journal Europe Sprl (n 185), 376 (per Lord Bingham); Flood $v$ Times Newspapers Ltd [2012] UKSC 11, [24] (per Lord Phillips).

188 Connick v Myers 461 US 138, 146 (1983).

189 Roth v United States 354 US 476, 484 (1957); New York Times v Sullivan 376 US 254, 269 (1964); Hustler Magazine v Falwell 485 US 46, 53 (1988); Lion Laboratories Ltd v Evans [1984] 1 WLR 526, 530; Francome v Mirror Group Newspapers Ltd [1984] 1 WLR 892, 897; Reynolds v Times Newspapers Ltd (n 185) 205 (per Lord Nicholls).

190 For a more comprehensive list, see Oster (n 82) 75.

191 Bowman v UK App No 141/1996/760/961 (ECtHR 19 February 1998), para 42; Jerusalem v Austria App No 26958/95 (ECtHR 27 February 2001), para 41; Filatenko v Russia App No 73219/01 (ECtHR 6 December 2007), para 40 
public administration and justice; 192 abuse of police power; 193 and criticisms of businesses and those operating businesses. ${ }^{194}$ Hence, according to the ECtHR, publishing material relating exclusively to private matters or on 'tawdry allegations' and 'sensational and ... lurid news, intended to titillate and entertain, which are aimed at satisfying the curiosity of a particular readership regarding aspects of a person's strictly private life' and serving to 'entertain' rather than 'educate' is not in the public interest. ${ }^{195}$ Rather, echoing the criticisms of the media operating within a libertarian framework discussed above, these situations referred to by the Strasbourg Court relate to mere entertainment, as opposed to meeting the standards or norms of public discourse set out on this section.

Thus, social responsibility ideology, together with the argument from democratic selfgovernance, endorses a two-tiered approach to media expression. Firstly, the framework dictates that the media's privileged protection is subject to it abiding by certain behavioural standards or norms, including acting ethically and in good faith, and publishing or broadcasting material that is based on reasonable research to verify the provenance of it and its sources. Incidentally, the only legal instruments that qualify the right to free speech with express reference to these extra duties and responsibilities are Article 10(2) ECHR and Article 19(3) of the International Covenant for Civil and Political Rights (ICCPR). Although these qualification clauses apply to both media and non-media entities, their main purpose is to provide member states with a tool to combat abuses of power by the media. ${ }^{196}$ Secondly, pursuant to the parameters, or norms, of speech set by the framework, public discussion should be protected. However, if the expression is not of public interest, it should not be afforded the same level of protection compared to that which is of public concern. This includes speech primarily concerned with commercial or financial matters, ${ }^{197}$ speech relating to private or intimate matters, ${ }^{198}$ and hate speech. ${ }^{199}$

192 De Haes and Gijsels v Belguim App No 19983/92 (ECtHR 24 February 1997), para 37; Pedersen and Baadsgaard v Denmark App No 49017/99 (ECtHR 17 December 2004) para 71; Perna v Italy App No 48898/99 (ECtHR 6 May 2003) para 39.

193 Thorgeir Thorgeirson v Iceland App No 13778/88 (ECtHR 25 June 1992).

194 Fressoz, and Roire v France App No 29183/95 (ECtHR 21 January 1999), para 50; Steel and Morris v UK App No 68416/01 (ECtHR 15 February 2005) para 89; J Oster, 'The criticism of trading corporations and their right to sue for defamation' (2011) 2 Journal of European Tort Law 255.

195 Mosley $v$ UK App No 48009/08 (ECtHR 10 May 2011) para 114; Von Hannover v Germany (No 1) App No 59320/00 (ECtHR 24 June 2004) para 65; Hachette Filipacchi Associes v France App No 12268/03 (ECtHR 23 July 2009) para 40; Eerikainen and Others v Finland App No 3514/02 (ECtHR 10 February 2009) para 62; Standard Verlags GmbH v Austria (No 2) App No 21277/05 (ECtHR 4 June 2009) para 52; MGN Ltd v UK App No 39401/04 (ECtHR 18 January 2011) para 143.

196 Oster (n 82) 72-3; These duties and responsibilities are particularly significant when applied as factors of the qualified privilege defence, as defined by Lord Nicholls in Reynolds v Times Newspapers (n 185) 205 (see also Jameel v Wall Street Journal Europe Sprl (n 185), 383 per Lord Hoffmann; Flood v Times Newspapers Ltd (n 187), [30] per Lord Phillips), and now enshrined within s 4 of Defamation Act 2013.

197 Barendt (n 33) 392-416; From a US Supreme Court perspective, see Central Hudson Gas \& Electric Corp v Public Service Commission 447 US 557 (1980); Dun \& Bradstreet Inc v Greenmoss Builders Inc 472 US 749, 762 (1985). For ECtHR jurisprudence, see Market Intern Verlag and Klaus Beerman v Germany App No 10572/83 (ECtHR 20 November 1989) para 33.

198 Barendt (n 33) 230; Fenwick and Phillipson (n 32) 661; P Keller, European and International Media Law: Liberal Democracy, Trade and the New Media (Oxford University Press 2011) 307; Von Hannover v Germany (No 1) (n 196) para 65; MGN Ltd v UK (n 195) para 143; Mosley v UK (n 195) para. 14.

199 Article 20(2) ICCPR states 'Any advocacy of national, racial or religious hatred that constitutes incitement to discrimination, hostility or violence shall be prohibited by law'. For example, see Ross v Canada App No 736/97 (UN Human Rights Committee, 18 October 2000) para 11.5. For ECtHR jurisprudence, see Lebideux and Isorni v France App No 55/1997/839/1045 (ECtHR, 23 September 1998) para 47; Norwood v UK App No 23131/03 (ECtHR, 16 November 2004). 
Consequently, and in conclusion, historically, due to its reach, it was incumbent upon the traditional media to disseminate matters of public interest, and to act as the public watchdog and Fourth Estate; to provide a check and balance on government. As a result, the ECtHR has consistently stated that media freedom provides one of the best means for the public to discover and form opinions about the ideas and attitudes of political leaders, and on other matters of general interest, and that the public has a right to receive this information. ${ }^{200}$ Pursuant to the jurisprudence of the Strasbourg Court, the concept of media freedom grants protection to those operating as media beyond that afforded to non-media actors by freedom of expression. ${ }^{201}$ However, media actors that are subject to these privileges, beyond private individuals, are also subject to duties and responsibilities in excess of those expected of non-media entities. The reach of the media does not just enable it to fulfil its constitutional functions. This power can be abused in equal measure: the potential impact of abuse of power is far greater than that emanating from private individuals, as the media is not just capable of invading private lives of individuals, or damaging reputations, but it can also shape and mislead public opinion, as demonstrated by the fake news phenomenon and the Cambridge Analytica scandal discussed earlier in this article. ${ }^{202}$ As established in Section 2 above, 'abuse' of this kind by the media is more likely if it is operating within a libertarian paradigm. Rather, the privilege afforded to the media, deriving from the ambit of the social responsibility theory and the argument from democratic self-governance, is based upon a utilitarian, consequentialist and functional understanding of media freedom. This means that within this normative and philosophical framework media actors are protected for disseminating matters of public interest and operating as the public watchdog/Fourth Estate and, therefore, fulfilling functions beneficial to society. However, this protection carries with it the obligation to fulfil these functions whilst behaving in a way that complies with the standards and norms discussed above. If it fails to do this, it relinquishes its protection and may be subject to regulatory sanctions and/or criminal or civil liability. The following section will set out how the social responsibility/argument from democratic self-governance paradigm advanced in this paper provides a mechanism for dealing with, at least some, of these abuses. In particular it will consider how it justifies (and provides) a normative framework from which to 'hang' regulation of the media.

\section{Conclusion: how a new normative and philosophical framework can right the wrongs of libertarianism}

As identified in Section 2, despite the emergence of social responsibility theory, its historical and ongoing marginalisation ${ }^{203}$ has become more acute as a result of libertarianism's position as the de facto normative paradigm for internet and social media expression. Consequently, some of the problems distilled by Siebert et al (as set out above $)^{204}$ that the Royal Commission and the Hutchins Commission were set up to consider and attempted to resolve, in respect of the traditional media through the creation of the theory, are being repeated, albeit within a modern media context. Through

200 Lingens v Austria App No 9815/82 (ECtHR, 8 July 1986) para 42; Oberschlick v Austria (No 1) App No 1162/85 (ECtHR 23 May 1991) para 58; Scharsach and News Verlagsgesellschaft v Austria App No 39394/98 (ECtHR, 13 November 2003) para 30.

201 Bladet Tromso and Stensaas v Norway (2000) 29 EHRR 125, [59]; Bergens Tidande v Norway (2001) 31 EHRR 16, [48]; Busuioc v Moldova (2006) 42 EHRR 14, [64]-[65]; Jersild v Denmark (1995) 19 EHRR 1; Janowski v Poland (No 1) (2000) 29 EHRR 705, [32]. See also Coe (n 11) 27-31.

202 See Sections 3.1 and 3.2 .

203 Christians et al (n 24) 38.

204 Siebert et al (n 16). 
recourse to the criticisms of libertarianism and, specifically, the argument from truth and marketplace of ideas set out in Section 3, this section will set out how (re)embracing social responsibility theory could go some way at least to solving these problems.

\section{1 'RESISTANCE' TO SOCIAL CHANGE AND THE POLARISATION OF COMMUNITIES: FACILITATING CULTURAL AND MEDIA PLURALITY}

Prima facie there is no doubt that social media speech and, in particular, the advent of citizen journalism has in many instances facilitated social change through its enablement of cultural pluralism and its fostering of the 'Great Communities' envisaged by the Hutchins Commission. This is particularly evident in the Arab World and the Middle East $^{205}$ where social media and citizen journalism have been hailed as tools for the empowerment of marginalized communities such as women and the youth, [and have] also brought new opportunities that have resulted in the breaking of the communication monopoly by those in power'. ${ }^{206}$ For example, the Arab Spring that began in Tunisia in December 2010 and ended in the revolution of 14 January 2011, and has since been followed in Egypt, Libya and Syria, illustrates social media's role in galvanising activists and facilitating social change. ${ }^{207}$ However, social media does not always stimulate social change; to the contrary, it can encourage social inertia. As identified above at Section 3.2, filter bubbles can actively undermine the marketplace of ideas by entrenching people's views. Rather than exposing us to new and opposing ideas and perspectives, these filter bubbles can create echo chambers, giving rise to what has been referred to as 'my news, my world'. 208 Thus, instead of being a catalyst for social change by encouraging cultural plurality and the galvanisation of 'Great Communities', filter bubbles and echo chambers can polarise communities, in particular already marginalised groups. ${ }^{209}$

It is recognised that re-embracing the social responsibility theory will not necessarily prevent echo chambers, as arguably they are an inherent characteristic of online speech, regardless of the underpinning normative paradigm. However, as the likes of Baran and Davis and Yu and Renderos have observed, social responsibility theory will continue to be revitalised by new and emerging technologies, such as social media and its facilitation of citizen journalism. ${ }^{210}$ It is submitted that the effect of this could be threefold: firstly, promotion of the underlying values of social responsibility theory, particularly its focus on cultural pluralism and media responsibility, may discourage the continued widespread implementation of filter bubbles which would actively reduce the amount of echo chambers we are inadvertently captured by; secondly, as social media and citizen journalism has the potential to give new strength to the social responsibility model, by virtue of its rationale, this rejuvenation of the theory may encourage more speech adhering to the theory's values. Thus, although not solving the echo chamber issue, it will encourage the dissemination of, and make available, more speech that complies with standard and norms of public discourse set out in Section 4; thirdly, as set out at Section 5.3 below, the social responsibility theory dictates that the government must actively

205 See generally D McGoldrick, 'The limits of freedom of expression on Facebook and social networking sites: A UK perspective' (2013) Human Rights Law Review 125-51, 130; Coe (n 63) 30; M Castells, M Fernandez-

Ardevol, J Qui and A Say, Mobile Communication and Society: A Global Perspective (MIT Press 2007).

206 N Miladi, 'Social media and social change' (2016) 25(1) Digest of the Middle East 36-51, 36.

207 Ibid 37.

208 Baran and Davis (n 3) 81.

209 See generally C. Sunstein, \#Republic (Princeton University Press 2017) ch 3.

210 Baran and Davis (n 3) 79; B Yu and S Renderos, 'Seizing the airwaves' (2013) (March) Extra! 12-13. 
promote the freedom of its citizens, ${ }^{211}$ which can be achieved, in part, by guaranteeing adequate media performance. ${ }^{212}$ Arguably, this includes the obligation to support diverse speech environments (in other words, 'Great Communities' that encourage cultural pluralism). More broadly, unlike libertarianism, it is submitted that the theory supports the notion of 'positive' free speech; as observed by a number of scholars, ${ }^{213}$ and the Grand Chamber of the ECtHR in Centro Europa 7 Srl $v$ Italy, the concept places positive obligations on the state to ensure media plurality (in addition to its negative duty of noninterference). ${ }^{214}$ This is equally important in respect of emerging technologies as it is with the traditional media as, according to Curran et al, the internet and, it is submitted, by extension, social media and citizen journalism, is not exempt from 'corporate dominance, market concentration, controlling gatekeepers, employee exploitation, manipulative rights management, economic exclusion through "tethered appliances" and encroachment upon the information commons'. ${ }^{215}$

\subsection{THE PROBLEM WITH 'RATIONALITY': DEALING WITH SENSATIONALISED STORIES, FAKE NEWS, ENTRENCHED VIEWS AND ANONYMOUS AND PSEUDONYMOUS SPEECH}

In contrast to libertarianism, social responsibility theory does not accept the proposition that we are innately driven to search for truth and use it as a guide, and it is, at best, sceptical of people's ability to think rationally, particularly in the context of the marketplace. It views us as being lethargic, prone to passively accepting what we see, hear and read and reluctant to apply reason when it does not satisfy our immediate needs and desires. Consequently, as Siebert et al state, the theory perceives us as being 'easy prey for demagogues, advertising pitchmen, and others who would manipulate [us] for their selfish ends'. 216 Thus, unlike libertarian ideology, the social responsibility theory acknowledges the inherent flaws in our nature. In applying this to a modern media context, and the discussions in Section 3, it recognises that we are vulnerable to sensationalised stories, fake news and the regurgitation of false or misleading information, entrenchment of views by virtue of preconceived schemas, the fact that we are largely unable to assess the veracity of anonymous and pseudonymous speakers and, as a result of all of this, our inability to rationally assess the marketplace. Consequently, it is realistic, as opposed to being idealistic.

Significantly, it is this pragmatism that makes it a suitable framework for the modern media, as the operation of media freedom is based upon its standards and norms of behaviour and discourse set out in Section 4 that facilitate effective democratic selfgovernance. Although not a panacea, this helps to protect us against some of the flaws and vulnerabilities in human nature outlined above, by virtue of the behaviours it requires. For instance, it may: mean that more care is taken over source-checking to reduce the regurgitation of false or misleading information; discourage the publication of sensationalised stories and encourage the dissemination of constitutionally valuable information; support the introduction by social media platforms, such as Facebook, of

\footnotetext{
211 Barendt (n 33) 36, 105-7.
}

212 Siebert et al (n 16) 95; W Hocking, Freedom of the Press: A Framework of Principle (University of Chicago Press 1947) 182-93; See also Özgür Gündem v Turkey (2001) 31 EHRR 1082, [43].

213 Kenyon (116) 391-402; T Emerson, The System of Freedom of Expression (Vintage 1970) 4; J Balkin, 'Some realism about pluralism: legal realist approaches to the First Amendment' [1990] Duke Law Journal 375, 401; A Hutchinson, 'Talking the good life: from free speech to democratic dialogue' (1989) 1 Yale Journal of Law and Liberation 17, 25; T Gibbons, 'Free speech, communication and the state' in M Amos, J Harrison and L Woods (eds), Freedom of Expression and the Media (Martinus Nijhoff 2012) 42.

214 [2012] ECHR 974, [134]; See also: Manole v Moldova [2010] ECHR 1112, [107].

215 Curran et al (n 138) 180.

216 Ibid. Siebert et al (n 16) 100. 
third-party fact-checking organisations to prevent the dissemination of fake news; as a result it means that the audience can have more faith in material published anonymously and pseudonymously without having to compromise the identity of the speaker and, ultimately, discourage such speech to the detriment of freedom of expression. Essentially, this normative and philosophical framework provides us with a more suitable platform from which to assess the marketplace rationally.

\subsection{A BASIS FOR COERCIVE REGULATION?}

Undoubtedly, both the traditional media and users of social media, including citizen journalists, can unjustifiably damage reputations ${ }^{217}$ and invade personal privacy. ${ }^{218}$ The social responsibility theory and argument from democratic self-governance framework offer two layers of protection against this. Publications that damage reputation and/or invade privacy without justification will fall short of the standards and norms of public discourse as they would not be in the public interest. As a result, these publications would not qualify for protection under media freedom.

An additional layer of protection for the rights of individuals that the framework supports is regulation. The Alliance of Independent Press Councils of Europe (AIPCE) ${ }^{219}$ is a network of national voluntary and self-regulatory media councils that was formed to deal with complaints from the public about editorial content. ${ }^{220}$ The AIPCE's councils were traditionally concerned with the print and broadcast media, but it has recently extended its remit to online versions of the traditional media and to bloggers and citizen journalists. Although there is no doubt that the print media has, and will continue to, publish stories via traditional methods and online that are morally questionable, cause reputational damage and invade individuals' privacy without just cause, according to the AIPCE, complaints made by the public against online blogs and citizen journalists for alleged breaches of journalistic ethical standards to its various councils continue to increase rapidly. 221 Thus, the AIPCE, its councils and ultimately the public, face three problems, as set out in the following paragraphs.

217 See generally Milo (n 113); P Coe, 'The Defamation Act 2013 and CPR 3.4 and 24: a sting in causation's tail' (2014) 25(3) Entertainment Law Review 93-6; P Coe 'The Defamation Act 2013: we need to talk about corporate reputation' (2015) 4 Journal of Business Law 313-34. In respect of social media, see Smith $v$ ADV FN plc [2008] EWHC 1797; McAlpine v Bercow [2013] EWHC 1342 (QB); Monroe v Hopkins [2017] EWHC $433(\mathrm{QB})$.

218 For the traditional media, see generally E Barendt, 'Privacy and freedom of speech' in A Kenyon and M Richardson (eds), New Dimensions in Privacy Law International and Comparative Perspectives (Cambridge University Press 2006) 11-31; R Wacks, Privacy and Media Freedom (Oxford University Press 2013); B Markesinis, Protecting Privacy (Oxford University Press 1999); R Barnes, Outrageous Invasions: Celebrities' Private Lives, Media and the Law (Oxford University Press 2010); Sir M Warby and N Moreham (eds), The Law of Privacy and the Media (Oxford University Press 2016). In respect of social media, notable examples have concerned the use of 'super-injunctions'. For example, see: CTB $v$ News Group Newspapers [2011] EWHC 1232. See generally Warby and Moreham (eds), ch 3; P Wragg, 'Protecting private information of public interest: Campbells great promise unfulfilled' (2015) 7 Journal of Media Law 225; R Barnes and P Wragg, 'Social media, sporting figures and the regulation of morality' in D Mangan and L Gillies (eds), The Legal Challenges of Social Media (Edward Elgar 2017) 155-76.

219 AIPCE < www.aipce.net>.

220 IPSO is a member. IMPRESS is not a member. These regulatory schemes are explained in more detail below.

221 A Hulin, 'Citizen journalism and news blogs: why Media Councils don't care (yet)' (Inforrm's Blog, 15 June 2016) <https://inforrm.org/2016/06/16/citizen-journalism-and-news-blogs-why-media-councils-dont-care-yetadeline-hulin/\#more-34437>. 
Firstly, from a UK perspective, the print media is not, at present, subject to a compulsory or coercive regulatory regime. As a result of Leveson LJ's Inquiry ${ }^{222}$ the Royal Charter on Self-Regulation of the Press created the Press Recognition Panel, a corporate body empowered to approve independent press regulators that fit the criteria imposed by the Charter. This led to the creation of two regulators: IMPRESS ${ }^{223}$ and its rival, the Independent Press Standards Organisation (IPSO), 224 which was created by the press industry itself. IMPRESS has the power to impose fines on its members who breach its code and offers an arbitration service that settles disputes without the need for litigation, whereas IPSO does not. Common to both schemes is their reliance on members of the press to voluntarily join them. Despite the self-regulatory nature of IMPRESS and IPSO, there is a framework in place for a coercive regime. In light of Leveson LJ's recommendations to 'encourage' press membership of IMPRESS, s 34 of the Crime and Courts Act 2013 enables a court to award exemplary damages against any 'relevant publisher' 225 in media litigation who is not a member of 'an approved regulator'. Among the requirements for an effective regulator is that it will have a low-cost arbitration system to reduce legal costs for both claimants and the press. Section 40 is at the core of this 'costs incentives regime' as it empowers the court to award adverse costs against nonmembers of an 'approved regulator' by forcing the 'relevant publisher' to pay the claimant's legal costs even if the publisher is successful in defending the claim, subject to certain exceptions. $^{226}$ However, s 40 is not yet in force. ${ }^{227}$ Consequently, it remains unenforceable until it is activated by the Secretary of State for Digital, Culture, Media and Sport. Thus, Leveson LJ's recommendations have only been partially implemented.

Secondly, s 40 and the abandoned amendment to the Data Protection Bill 228 are controversial. For example, the Daily Mail cited an opinion by Antony White QC suggesting that the amendment to the Bill would violate human rights law. ${ }^{22}$ The press used the same argument to challenge s 40 in 2013. ${ }^{230}$ However, these arguments are flawed. The human rights relied upon pursuant to the ECHR ${ }^{231}$ are all qualified rights, meaning their interference is lawful so long as it is justified and proportionate. It is submitted that these provisions are justified and proportionate, as s 40 could effectively balance the right to free speech with the rights of the public. This is because publishers who refuse to join an approved regulator deny claimants access to quick and cheap

222 Leveson (n 148).

223 IMPRESS < https://impress.press $>$.

224 IPSO <www.ipso.co.uk>.

$225 \mathrm{~S} 41$ sets out what is meant by 'relevant publisher. This is qualified by Schedule 15 which excludes certain persons and organisations from this definition and, therefore, from the ambit of ss 34 to 42 . The scope of s 41 is discussed in the following paragraph.

226 These exceptions are dealt with below.

227 Abandoned amendments to the Data Protection Bill proposed by Labour's Tom Watson would have mirrored the wording of s 40 (in the Data Protection Act 2018), albeit in respect of data breaches by 'relevant publishers'.

228 Ibid. The Bill received Royal Assent on 23 May 2018 and the Act's main provisions commenced on 25 May 2018.

229 I Drury, 'Labour's plans for two-tier press regulation that would favour supportive Guardian over other newspapers would be illegal, warns a leading QC' (Mail Online, 7 May 2018) <www.dailymail.co.uk/news/article-5697875/A-chilling-assault-Press-freedom-Labour-illegal-warns-leadingQC.html>.

$230 \mathrm{H}$ Tomlinson QC, 'The Data Protection Bill, human rights and the Daily Mail (Inforrm's Blog, 8 May 2018) <https://inforrm.org/2018/05/08/the-data-protection-bill-human-rights-and-the-daily-mail-hughtomlinson-qc/\#more-39917>.

231 Article 6 access to a court; Article 10 freedom of expression; Article 14 right not to be discriminated against. 
dispute resolution. Consequently, they should pay for that decision, which would otherwise impose costs on potential victims or deny them a remedy. As Hugh Tomlinson QC states:

Publishers have been given a choice that no other business or profession is given: they can choose whether or not to be subject to effective scrutiny. If they choose not to, then they must pay to ensure that victims have access to justice ... There is no threat to press freedom or human rights - simply a threat to unregulated press abuse. ${ }^{232}$

Furthermore, s 40 is subject to exceptions to the rule that publishers who reject independent regulation pay whether they win or lose. The court can refuse to follow it if it is 'just and equitable' to make a different award. This would apply, for example, if the claimant's case was frivolous or if the claimant had refused a reasonable settlement. Thus, the system retains flexibility to enable the courts to do justice whilst providing an incentive for publishers to join a system that gives claimants access to justice.

If media actors do not join, or comply with, an approved regulatory scheme, that sets ethical standards and provides an appropriate mechanism for redress, then curing the 'real harm caused to real people' by breaches of these standards creates a challenge. Indeed, Leveson LJ's findings were influenced by the evidence of Baroness O'Neill, who has long held the view that media freedom and individual freedom of expression are distinct concepts. ${ }^{233}$ Accordingly, to O’Neill, the public interest in press freedom:

$\ldots$ is best construed as an interest in adequate (or better than adequate) standards of public communication, that allow readers, listeners and viewers to gain information and form judgements, as so to participate in social, cultural and democratic life. A free press is a public good because it is needed for civic and common life. 234

According to Wragg, ${ }^{235}$ this view is representative of the claim made by social responsibility theorists that the media's performance of its functions is critical to ensuring participation in the democratic process. ${ }^{236}$ In their view, regulation of the media is justified by this rationale on the basis that it protects and enhances media freedom, which in turn safeguards society's interest in a healthy and functioning democracy. To their mind, regulation ensures that the media achieves this aim, as the media cannot be trusted to do so without it. ${ }^{237}$

It is submitted that the framework advanced in this article provides a mechanism to deal with this challenge, as it justifies a tougher regulatory regime for all media actors. Unlike libertarianism, the social responsibility paradigm champions media self-regulation where possible, but also acknowledges that a coercive regime may be necessary. ${ }^{238}$ Under the theory, the government must not merely allow freedom, it must also actively promote

232 Tomlinson (n 230).

233 See above (n 148).

234 Ibid.

235 P Wragg, A Free and Regulated Press: Defending Coercive Independent Press Regulation (Hart Publishing, forthcoming).

236 For example, see R Post, 'The constitutional concept of public discourse: outrageous opinion, democratic deliberation and Hustler Magazine v Falwell (1990) 64 Harvard Law Review 255, 308; 'Meiklejohn's mistake: individual autonomy and the reform of public discourse' (1993) 64 University of Colorado Law Review 1109; 'Participatory democracy and free speech' (2011) 97 Virginia Law Review 477; J Habermas, The Theory of Communicative Action, vols 1 and 2 (Polity Press 1986); J Rawls, Political Liberalism (Columbia University Press 1996).

237 Wragg (n 235).

238 Weiss (n 13) 577; Siebert et al (n 16) 76. 
it, which means that when necessary the government should act to protect the freedom of its citizens. ${ }^{239}$ Inherent within this obligation is the government's status as the 'residuary legatee of responsibility for an adequate press performance'. ${ }^{240}$ Thus, according to Hocking, if a self-regulating media is insufficient to provide society with the services it requires from it then the government is obliged to correct this by, for instance, enacting legislation to forbid flagrant abuses of the media which may 'poison the wells of public opinion'.241 Arguably, in respect of 'relevant publishers', s 40 of the Crime and Courts Act 2013 would achieve this. However, the theory dictates that any government intervention should only occur when the 'need is great and the stakes are high', and even then it should intervene cautiously. ${ }^{242}$ As Siebert et al state, under the theory, 'the government should not act with a heavy hand' as any 'agency capable of promoting freedom is also capable of destroying it'.243

Thirdly, online news bloggers and citizen journalists rarely join the various selfregulatory systems that exist across Europe. ${ }^{244}$ Indeed, in his Inquiry, Leveson LJ stated that the internet is an: 'ethical vacuum ... [that] does not claim to operate by express ethical standards, so that bloggers and others may, if they choose, act with impunity'245 and, specifically, ' $[\mathrm{b}] \operatorname{logs}$ and other such websites are entirely unregulated'.246 Consequently, cyberspace has been described as a 'Wild West, law free zone'. ${ }^{247}$ As a result, those councils that can only deal with complaints against their members are hamstrung when it comes to investigating complaints against non-members. ${ }^{248}$ In the UK this issue has not been helped by the Crime and Courts Act 2013. As stated above, ss 34 and 40 of the Act apply to any 'relevant publisher'. According to s 41(1) a 'relevant publisher' is a person who, in the course of a business, ${ }^{249}$ publishes news-related material that is written by different authors and is subject to editorial control. Section 41(2) tells us that this means that a person, who does not have to be the publisher, has editorial or equivalent responsibility for the content and presentation of the material, and the decision to actually publish it. Crucially, s 41 seems to exclude most, if not all, citizen journalists for two reasons. By definition, most citizen journalists are not publishing news-related material 'in the course of a business'. Moreover, citizen journalists tend to be both the author and publisher of their material, as opposed to publishing material 'written by different authors'.

Although Leveson LJ's Inquiry was exclusively concerned with the print media, his view that greater press regulation is required to prevent 'real harm caused to real people 250 is equally as applicable to media actors operating online and via social media,

239 Siebert et al (n 16) 95.

240 Hocking (n 212) 182-93.

241 Ibid.

242 Siebert et al (n 16) 95.

243 Ibid 95-6.

244 Leveson (n 148).

245 Ibid [3.2].

246 Ibid 171, [4.20].

247 A Yen, 'Western frontier or feudal society? Metaphors and perceptions of cyberspace' (2002) 17 Berkeley Technology Law Journal 1207.

248 For example, the Austrian and Dutch Councils and the French and Flemish Councils in Belgium will investigate complaints about any media content, regardless of the publisher. Norway's Council has recently enacted a rule change to enable it to deal with complaints against non-members. ibid.

249 Whether or not carried on with a view to make a profit.

250 Leveson (n 148) 50, [2.2]. 
including citizen journalists. Thus, it is submitted that the Crime and Courts Act 2013's definition of 'relevant publisher' is fundamentally flawed: why should traditional media actors, whether they publish material in their newspapers or online, be captured by ss 34 and 40 (if it were enacted), yet citizen journalists, by virtue of not publishing in the course of a business and being both the authors and publishers of their material, not be? Surely, if citizen journalists are acting as media they should then be subject to the same regulatory schemes as traditional journalists? Data protection law demonstrates the inequity of this situation. Pursuant to the jurisprudence of the European Court of Justice (as it then was), ${ }^{251}$ the UK Supreme Court ${ }^{252}$ and guidance from the Information Commissioner's Office (ICO), ${ }^{253}$ 'journalism' has been given a very wide meaning. Thus, in The Law Society and others $v$ Kordowski, ${ }^{254}$ Tugendhat J held that online bloggers engaging in internet journalism are able to avail themselves of the 'special purposes' exemption for 'journalistic, literary or artistic' purposes ${ }^{255}$ found in s 32 of the Data Protection Act 1998, and subsequently imported into Article 85 of the General Data Protection Regulation (GDPR) and the Data Protection Act 2018. ${ }^{256}$ According to the ICO, the purpose of the exemption is to 'safeguard freedom of expression'.257

This is a loophole that needs to be addressed. It is submitted that adopting the framework advanced in this article provides normative and philosophical support for the Crime and Courts Act 2013 regime that achieves a fair balance between media freedom and the rights of the public. Unfortunately, the regime excludes what is now a large and important group within the modern media: citizen journalists and online bloggers. In the same way it does in respect of the traditional media, the framework would support an amendment to the relevant 2013 Act provisions to explicitly include online media, or the introduction of new citizen journalist-specific legislation.

251 Tietosuojavaltuutettu v Satakunnan Markkinapörssi Oy Satamedia Oy (Satamedia) Case C-73/07.

252 Sugar (Deceased) v BBC [2012] UKSC 4.

253 Data Protection and Journalism: A Guide for the Media (Information Commissioners' Office 2014) 29-30 $<$ https://ico.org.uk/media/for-organisations/documents/1552/data-protection-and-journalism-mediaguidance.pdf $>$.

254 [2014] EMLR 2, [99].

255 The provision provides an exemption from most statutory provisions under the 1998 Act/GDPR which apply to the processing of personal data so long as the criteria found in s 32(1)(a)-(c) are met.

256 The exemption has been imported into the Data Protection Act 2018 by virtue of Part 5, para 26 of Schedule 2. Both the GDPR and 2018 Act have added 'academic purposes' to the list.

257 Information Commissioners' Office (n 253) 28. 
